Article

\title{
Optimizing the Regional Industrial Structure Based on the Environmental Carrying Capacity: An Inexact Fuzzy Multi-Objective Programming Model
}

\section{Wenyi Wang and Weihua Zeng *}

School of Environment, Beijing Normal University, No. 19, XinJieKouWai Street, HaiDian District, Beijing 100875, China; E-Mail: wwysee@mail.bnu.edu.cn

* Author to whom correspondence should be addressed; E-Mail: zengwh@bnu.edu.cn; Tel.: +86-010-5989-3162; Fax: +86-010-5989-3162.

Received: 24 September 2013; in revised form: 2 December 2013 / Accepted: 5 December 2013 / Published: 13 December 2013

\begin{abstract}
An inexact fuzzy multi-objective programming model (IFMOP) based on the environmental carrying capacity is provided for industrial structure optimization problems. In the IFMOP model, both fuzzy linear programming (FLP) and inexact linear programming (ILP) methods are introduced into a multi-objective programming framework. It allows uncertainties to be directly communicated into the problem solving processing, and it can effectively reflect the complexity and uncertainty of an industrial system without impractical simplification. The two objective functions utilized in the optimization study are the maximum total output value and population size, and the constraints include water environmental capacity, water resource supply, atmospheric environmental capacity and energy supply. The model is subsequently employed in a realistic case for industrial development in the Tongzhou district, Beijing, China. The results demonstrate that the model can help to analyze whether the environmental carrying capacity of Tongzhou can meet the needs of the social economic objectives in the new town plan in the two scenarios and can assist decision makers in generating stable and balanced industrial structure patterns with consideration of the resources, energy and environmental constraints to meet the maximum social economic efficiency.
\end{abstract}

Keywords: energy; environmental carrying capacity; fuzzy model; industrial structure; multi-objective 


\section{Introduction}

To some extent, industrial structure evolution reflects the seedtime and the evolutionary capability of a regional economy. It is also an important link between economic activities and the ecological environment, and the mode of the industrial structure has a direct impact on environmental protection and economic development.

With the advancement of the "sustainable development" concept [1] and the development of ecology, the relationship between people and nature has become a priority. It is clearly unilateral and unscientific to evaluate the industrial structure only from the perspective of economic growth. The water environmental capacity, water resource supply, atmospheric environmental capacity and energy supply are factors that should be considered when evaluating industrial structure.

The study of environmental carrying capacity evolved from the study of land carrying capacity in ecology and the concept of environmental capacity. As Bishop noted, environmental capacity is the intensity of human activity that can be permanently hosted in a region while maintaining an acceptable standard of living [2]. The purpose of this research is to analyze whether water environmental capacity, water resource supply, atmospheric environmental capacity and energy supply can meet the needs of planned economic and population development objectives and to propose some suggestions on industrial structure adjustments for decision makers.

The environmental carrying capacity can be altered by human activity [3], and it can be improved to some extent by regulating the economic structure. It is necessary to upgrade the structure of industry based on environmental carrying capacity. Tongzhou District is less developed and is poor in resources and environmental quality. Insufficient water resources and serious water pollution are the main issues in Tongzhou [4]. The focus of the new town plan for Tongzhou is to greatly develop the tertiary sector and improve the industrial level and technology. The plan is to build Tongzhou into the sub-center of Beijing to absorb excess population from the central urban area and expand industry and other urban functions. Tongzhou District is positioned as a "regional service center, the cultural industry base and waterfront livable city" and "a comprehensive service-oriented new town and an important base for Bohai Sea-Rim regional cooperation in Beijing".

There are questions about whether these targets are reasonable and whether the environment and energy are sufficient for the economic and population development needs. The industrial structure optimization model based on the environmental carrying capacity was established to answer these questions.

There has been a considerable number of studies concerning the economic, environmental and energy impacts of industrial optimization in recent decades [5-7]. Uncertainty is widely prevalent in these studies of industrial structure adjustment. As a result, uncertain optimization methods have been developed further. These techniques could be grouped into four categories:

Fuzzy model programming (FMP) [8-13]: $\mathrm{Wu}$ and $\mathrm{Xu}$ provided a system dynamics and fuzzy multi-objective programming integrated model to analyze the energy demand and $\mathrm{CO}_{2}$ emission in the economy-energy system. Giannoccaro et al. [9] used fuzzy set theory to model the uncertainty in supply chain (SC) inventory management policy. Rong and Lahdelma represented the uncertainty based on fuzzy set theory to optimize the scrap charge in secondary steel production. Petrovic et al. [11] developed a fuzzy model to determine the order quantities for inventory in a SC with uncertainties. Salema et al. [12] designed an optimization model of a reverse distribution network based on fuzzy theory. 
Shahnazari-Shahrezaei et al. [13] used a fuzzy multi-objective programming model to solve manpower scheduling problems in production and service environments.

Interval model programming (IMP) [14-16]: Qin and $\mathrm{Xu}$ [14] designed a two-step interval programming model to support urban water supply analysis under uncertainty. Simic and Dimitrijevic [15] proposed a risk explicit interval programming model for optimal long-term planning of vehicle recycling. Dong et al. [16] proposed an interval-parameter minimax regret programming (IMRP) method to support power management system planning under uncertainty.

Stochastic model programming (SMP) [17-21]: Sabri and Beamon [17] used stochastic methodology to design a multi-objective model for use in simultaneous strategic and operational supply chain planning. Shastri and Diwekar [18] developed a two-stage stochastic programming model to identify the optimal locations of sensors from an economic perspective. Guan and Philpott [19] proposed a multistage stochastic programming method for production planning in the New Zealand dairy industry. Ahmed et al. [20] developed a multi-stage stochastic integer programming model for an economies of scale of expansion costs in an uncertain environment. Kouwenberg [21] proposed a multi-stage stochastic programming model for asset liability management of a Dutch pension fund.

Hybrid mathematical programming [22-26]: Gu [22] designed an inexact stochastic fuzzy programming (ISFP) model for industrial structure optimization. Li and Zhang [23] proposed a fuzzy-stochastic model to simulate groundwater flow and contaminant transport under uncertainty. Lacagnina and Pecorella [24] presented a multistage stochastic soft constraints fuzzy programming model to solve a portfolio management problem. Li and Chen [25] developed a fuzzy-stochastic-interval linear programming (FSILP) method for supporting municipal solid waste management. Li [26] established an optimization model to determine the environmental carrying capacity of Wuhan city using an inexact fuzzy multi-objective programming (IFMOP) method. IFMOP allows uncertainties presented as intervals to be directly communicated into the planning processes through an interval linear programming algorithm [27,28]. The interactive approach of this method helps account for the indispensable involvement of stakeholders [29]. IFMOP has been successfully used in engineering applications, such as in regional new-zone development planning [30] and environmental and economic management [31].

However, most studies have focused on microeconomic industrial processes [32,33], which omit the whole industrial structure optimization at the environment carrying capacity level and do not take the primary sector system into account. Moreover, many studies have obtained results from only one scenario [34]. However, in the actual decision-making process, some alternatives should be provided for decision makers to choose the best policy. Most importantly, parameter uncertainties exist in the industrial structure optimization models. The methodology of IFMOP is suitable for solving industrial optimization models based on environment carrying capacity. The developed model can address dynamic, uncertain and multi-objective problems, as well as those in the environmental, energy and industrial management system [35].

The major originalities of this research are as follows:

- The industrial structure optimization model was established at the environment carrying capacity level. 
- The fuzzy linear programming (FLP) and inexact linear programming (ILP) methods are introduced into the optimization model to reflect the complexity and uncertainty.

- The whole industrial structure optimization was considered in the research, including the primary, secondary and tertiary sectors.

- The study was performed under the business-as-usual scenario [36] and the sustainable development scenario [36], taking the water environmental capacity, water resource supply, atmospheric environmental capacity and energy supply as constraints.

\section{Environmental Carrying Capacity}

The environmental carrying capacity is the limit of human activities over a given period that can be borne by the environment under the "no qualitative change to the environment" condition. The limiting factors refer to water environmental capacity, water resource supply, atmospheric environmental capacity and energy supply. Human activities can be expressed as the size of the population and the economy. Thus, the environmental carrying capacity can be represented as the maximum population size and total output value that the environment can withstand. Due to the openness and complexity of the environmental system, as well as the limitations of human knowledge, it is rational to quantitatively describe the environmental carrying capacity with uncertainty.

\section{Model}

\subsection{Methodology}

A general IFMOP model with discrete interval parameters can be formulated as follows [29]:

$$
\begin{gathered}
\text { Min } \quad f_{k}^{ \pm}=C_{k}^{ \pm} X^{ \pm}, \quad k=1,2, \ldots \\
\operatorname{Max} \quad f_{l}^{ \pm}=C_{l}^{ \pm} X^{ \pm}, \quad l=p+1, p+2, \ldots \\
A_{i}^{ \pm} X^{ \pm} \leq b_{i}^{ \pm}, \quad i=1,2, \ldots \\
A_{j}^{ \pm} X^{ \pm} \geq b_{j}^{ \pm}, \quad j=m+1, m+2, \ldots \\
X^{ \pm} \geq 0
\end{gathered}
$$

where $\mathrm{X}^{ \pm} \in\left\{\mathrm{R}^{ \pm}\right\}^{\mathrm{t} \times 1}, \mathrm{C}_{\mathrm{k}}{ }^{ \pm} \in\left\{\mathrm{R}^{ \pm}\right\}^{1 \times \mathrm{t}}, \mathrm{C}_{\mathrm{l}}^{ \pm} \in\left\{\mathrm{R}^{ \pm}\right\}^{1 \times \mathrm{t}}, \mathrm{A}_{\mathrm{i}}{ }^{ \pm} \in\left\{\mathrm{R}^{ \pm}\right\}^{1 \times \mathrm{t}}, \mathrm{A}_{\mathrm{j}}{ }^{ \pm} \in\left\{\mathrm{R}^{ \pm}\right\}^{1 \times \mathrm{t}}$ and $\mathrm{R}^{ \pm}$denote a set of inexact interval numbers. An inexact number $\mathrm{X}^{ \pm}$is defined as an interval with known upper and lower bounds. All parameters are intervals without distribution information.

The solution process is as follows: (a) optimize every single objective, (b) establish the pay-off matrix, (c) decompose the objective functions, (d) introduce the fuzzy operator and build the sub-models, and (e) solve the generated sub-models [26,37].

\subsubsection{Fuzzy Linear Programming (FLP) Transformation and Fuzzy Goals}

A fuzzy goal can be achieved by specifying an "aspiration level" and "inferior" for each objective or constraint [38]. Model (1) can be transformed into the following form with the minimum operator $\lambda^{ \pm}$. 


$$
\begin{gathered}
\max \lambda^{ \pm} \\
\text {s.t. } f_{k}^{ \pm}\left(X^{ \pm}\right) \leq f_{k}^{+}-\lambda^{ \pm}\left(f_{k}^{+}-f_{k}^{-}\right), k=1,2, \ldots, p \\
f_{l}^{ \pm}\left(X^{ \pm}\right) \geq f_{l}^{-}+\lambda^{ \pm}\left(f_{l}^{+}-f_{l}^{-}\right), l=p+1, p+2, \ldots, q \\
A_{i}^{ \pm} X^{ \pm} \leq b_{i}^{+}-\lambda^{ \pm}\left(b_{i}^{+}-b_{i}^{-}\right), i=1,2, \ldots, m \\
A_{j}^{ \pm} X^{ \pm} \geq b_{j}^{-}+\lambda^{ \pm}\left(b_{j}^{+}-b_{j}^{-}\right), j=m+1, m+2, \ldots, n \\
X^{ \pm} \geq 0 \\
0 \leq \lambda^{ \pm} \leq 1
\end{gathered}
$$

First, every single-objective model is solved. The form of every objective function is as Equation 1a or $1 \mathrm{~b}$, and the forms of the constraints are as Equation 1c-e. The solutions forms are as follows:

$$
\begin{aligned}
X^{ \pm(k)} & =\left\{x_{1}^{ \pm(k)}, x_{2}^{ \pm(k)}, \ldots, x_{l}^{ \pm(k)}\right\} \\
X^{ \pm(l)} & =\left\{x_{1}^{ \pm(l)}, x_{2}^{ \pm(l)}, \ldots, x_{l}^{ \pm(l)}\right\}
\end{aligned}
$$

Second, a set of objective function values can be obtained by $X^{ \pm(k)}$ and $X^{ \pm(l)}$, and the matrix is constructed as follows:

$$
\begin{gathered}
f_{1}^{ \pm}\left(X^{ \pm(w)}\right)=\left\{f_{1}^{ \pm}\left(X^{ \pm(1)}\right), f_{1}^{ \pm}\left(X^{ \pm(2)}\right), \ldots, f_{1}^{ \pm}\left(X^{ \pm(p)}\right), \ldots, f_{1}^{ \pm}\left(X^{ \pm(q)}\right)\right\} \\
f_{2}^{ \pm}\left(X^{ \pm(w)}\right)=\left\{f_{2}^{ \pm}\left(X^{ \pm(1)}\right), f_{2}^{ \pm}\left(X^{ \pm(2)}\right), \ldots, f_{2}^{ \pm}\left(X^{ \pm(p)}\right), \ldots, f_{2}^{ \pm}\left(X^{ \pm(q)}\right)\right\} \\
\vdots \\
f_{q}^{ \pm}\left(X^{ \pm(w)}\right)=\left\{f_{q}^{ \pm}\left(X^{ \pm(1)}\right), f_{q}^{ \pm}\left(X^{ \pm(2)}\right), \ldots, f_{q}^{ \pm}\left(X^{ \pm(p)}\right), \ldots, f_{q}^{ \pm}\left(X^{ \pm(q)}\right)\right.
\end{gathered}
$$

Then, "aspiration level" and "inferior" can be obtained.

"Aspiration level":

$$
\begin{aligned}
& \left(f_{k}^{-}\right)=\min \left\{f_{k}^{-}\left(X^{ \pm(w)}\right) \mid w=1,2, \ldots, p, p+1, \ldots, q\right\}, k=1,2, \ldots, p \\
& \left(f_{l}^{+}\right)=\max \left\{f_{l}^{+}\left(X^{ \pm(w)}\right) \mid w=1,2, \ldots, p, p+1, \ldots, q\right\}, k=1,2, \ldots, p
\end{aligned}
$$

"Inferior":

$$
\begin{gathered}
\left(f_{k}^{+}\right)=\max \left\{f_{k}^{+}\left(X^{ \pm(w)}\right) \mid w=1,2, \ldots, p, p+1, \ldots, q\right\}, k=1,2, \ldots, q \\
\left(f_{l}^{-}\right)=\min \left\{f_{l}^{-}\left(X^{ \pm(w)}\right) \mid w=1,2, \ldots, p, p+1, \ldots, q\right\}, k=1,2, \ldots, q
\end{gathered}
$$

\subsubsection{Inexact Linear Programming (ILP) Transformation}

The bound of operator $\lambda^{ \pm}$may not function consistently with all objective functions and constraints [27]. A method to alleviate this problem is to bring two individual operators $\lambda_{1}{ }^{ \pm}$and $\lambda_{2}{ }^{ \pm} . \lambda_{1}{ }^{ \pm}$is for Equations $2 \mathrm{~b}$ and $2 \mathrm{~d}$ with " $\leq$ " constraints, whereas $\lambda_{2}{ }^{ \pm}$is for Equations $2 \mathrm{c}$ and $2 \mathrm{e}$ with " $\geq$ " constraints. Then, we get:

$$
\max \lambda_{1}^{ \pm}+\lambda_{2}^{ \pm}
$$




$$
\begin{gathered}
\text { s.t. } f_{k}^{ \pm}\left(X^{ \pm}\right) \leq f_{k}^{+}-\lambda_{1}^{ \pm}\left(f_{k}^{+}-f_{k}^{-}\right), k=1,2, \ldots, p \\
f_{l}^{ \pm}\left(X^{ \pm}\right) \geq f_{l}^{-}+\lambda_{2}^{ \pm}\left(f_{l}^{+}-f_{l}^{-}\right), l=p+1, p+2, \ldots, q \\
A_{i}^{ \pm} X^{ \pm} \leq b_{i}^{+}-\lambda_{1}^{ \pm}\left(b_{i}^{+}-b_{i}^{-}\right), i=1,2, \ldots, m \\
A_{j}^{ \pm} X^{ \pm} \geq b_{j}^{-}+\lambda_{2}^{ \pm}\left(b_{j}^{+}-b_{j}^{-}\right), j=m+1, m+2, \ldots, n \\
X^{ \pm} \geq 0 \\
0 \leq \lambda_{1}^{ \pm} \leq 1 \\
0 \leq \lambda_{2}^{ \pm} \leq 1
\end{gathered}
$$

In the multi-objective problem, the sign distributions of the objective function coefficients are often different. Consequently, a sign decomposition method can be used to solve the problem. The objective function can be broken down into two sub-objectives, one of which is a maximum, and the other is a minimum. Thus, the coefficients of the decomposed sub-objective function are all positive, and the ILP algorithm can be used to solve it.

\subsubsection{IFMOP Sub-Models}

Through the above conversion process, we get two sub-models:

$$
\begin{gathered}
\max \lambda_{1}^{-}+\lambda_{2}^{+} \\
\text {s.t. } \sum_{s=1}^{t} c_{k^{\prime} s}^{+} x_{s}^{+} \leq f_{k^{\prime}}^{+}-\lambda_{1}^{-}\left(f_{k^{\prime}}^{+}-f_{k^{\prime}}^{-}\right), k^{\prime}=1,2, \ldots, q^{\prime} \\
\sum_{s=1}^{t}\left|a_{i s}\right|^{-} \operatorname{Sign}\left(a_{i s}^{ \pm}\right) x_{s}^{+} \leq b_{i}^{+}-\lambda_{1}^{-}\left(b_{i}^{+}-b_{i}^{-}\right), i=1,2, \ldots, m \\
\sum_{s=1}^{t} c_{l^{\prime} s}^{+} x_{s}^{+} \geq f_{l^{\prime}}^{+}+\lambda_{2}^{+}\left(f_{l^{\prime}}^{+}-f_{l^{\prime}}^{-}\right), l^{\prime}=q^{\prime}+1, q^{\prime}+2, \ldots, p^{\prime} \\
\sum_{s=1}^{t}\left|a_{j s}\right|^{-} \operatorname{Sign}\left(a_{j s}^{ \pm}\right) x_{s}^{+} \geq b_{j}^{-}+\lambda_{2}^{+}\left(b_{j}^{+}-b_{j}^{-}\right), j=m+1, m+2, \ldots, n \\
x_{s}^{+} \geq 0, s=1,2, \ldots, t \\
0 \leq \lambda_{1}^{-} \leq 1,0 \leq \lambda_{2}^{+} \leq 1
\end{gathered}
$$

and

$$
\begin{gathered}
\max \lambda_{1}^{+}+\lambda_{2}^{-} \\
\text {s.t. } \sum_{s=1}^{t} c_{k^{\prime} s}^{-} x_{s}^{-} \leq f_{k^{\prime}}^{+}-\lambda_{1}^{+}\left(f_{k^{\prime}}^{+}-f_{k^{\prime}}^{-}\right), k^{\prime}=1,2, \ldots, q^{\prime} \\
\sum_{s=1}^{t}\left|a_{i s}\right|^{+} \operatorname{Sign}\left(a_{i s}^{ \pm}\right) x_{s}^{-} \leq b_{i}^{+}-\lambda_{1}^{+}\left(b_{i}^{+}-b_{i}^{-}\right), i=1,2, \ldots, m \\
\sum_{s=1}^{t} c_{l^{\prime} s}^{-} x_{s}^{-} \geq f_{l^{\prime}}^{+}+\lambda_{2}^{-}\left(f_{l^{\prime}}^{+}-f_{l^{\prime}}^{-}\right), l^{\prime}=q^{\prime}+1, q^{\prime}+2, \ldots, p^{\prime}
\end{gathered}
$$




$$
\begin{aligned}
\sum_{s=1}^{t}\left|a_{j s}\right|^{+} \operatorname{Sign}\left(a_{j s}^{ \pm}\right) x_{s}^{-} & \geq b_{j}^{-}+\lambda_{2}^{-}\left(b_{j}^{+}-b_{j}^{-}\right), j=m+1, m+2, \ldots, n \\
x_{s}^{-} & \geq 0, s=1,2, \ldots, t \\
x_{s}^{-} & \leq x_{s, \mathrm{opt}}^{+}, s=1,2, \ldots, t \\
& \leq \lambda_{1}^{+} \leq 1,0 \leq \lambda_{2}^{-} \leq 1
\end{aligned}
$$

With the two sub-models, the decision variable $\left(\mathrm{x}^{ \pm}{ }_{\mathrm{s}, \mathrm{opt}}\right)$ solutions can be obtained [38]. Thus, solutions for the objective function ( $\mathrm{f}_{\mathrm{k}}^{ \pm}$and $\mathrm{f}_{1}^{ \pm}$) can be obtained by model (1) and $\mathrm{x}_{\text {s,opt }}^{ \pm}$In this study, an IFMOP model was established to determine the scale and structure of the economy and the population under the environment, resource and energy constraints. Lingo was used to solve the IFMOP model following the steps, and the software version was lingo 8.0.

\subsection{The Objective Function}

The inexact uncertain multi-objective programming model of the environmental carrying capacity includes two objective functions: the maximum value of the total output maxF (endogenous variable) and the maximum size of the population maxP (endogenous variable). The objective function maxF represents the maximum value of the total output after deducting the expenses of sewage and solid waste disposal. The value of the total output refers to the three industrial output values in Tongzhou district, and the secondary sector consists of 11 industries. The centralized treatment of sewage and solid waste with a fee-charge is a key measure for pollution prevention, and the corresponding expenses are introduced to the objective functions rationally. The sewage (solid waste) includes production sewage (solid waste) and living sewage (solid waste). MaxP expresses the maximum size of the population in Tongzhou district by the parameters of the number of employees and the ratio of employment to population.

$$
\begin{aligned}
\max F= & {\left[A G D^{ \pm}+\sum_{j=1}^{m}\left(I N D_{j}^{ \pm}\right)+S E D^{ \pm}\right] } \\
& -\left[\left(A G D^{ \pm}\right)(A G W W T)\left(A G W W D^{ \pm}\right)\left(W W C^{ \pm}\right)+\left(A G D^{ \pm}\right)(A G W S T)\left(A G W S D^{ \pm}\right)\left(W S C^{ \pm}\right)\right. \\
& +\sum_{j=1}^{m}\left(I N D_{j}^{ \pm}\right)\left(I N W W T_{j}^{ \pm}\right)\left(I N W W D_{j}^{ \pm}\right)\left(W W C^{ \pm}\right)+\sum_{j=1}^{m}\left(I N D_{j}^{ \pm}\right)\left(I N W S T_{j}^{ \pm}\right)\left(I N W S D_{j}^{ \pm}\right)\left(W S C^{ \pm}\right) \\
& \left.+\left(S E D^{ \pm}\right)\left(S E W W T^{ \pm}\right)\left(S E W W D^{ \pm}\right)\left(W W C^{ \pm}\right)+\left(S E D^{ \pm}\right)\left(S E W S T^{ \pm}\right)\left(S E W S D^{ \pm}\right)\left(W S C^{ \pm}\right)\right] \\
& -\left\{\frac{1}{p^{ \pm}}\left(P W W D^{ \pm}\right)\left(P W W T^{ \pm}\right)\left(W W C^{ \pm}\right)\left[\sum_{j=1}^{m}\left(I N D_{j}^{ \pm}\right)\left(I N M P_{j}^{ \pm}\right)+\left(A G D^{ \pm}\right)\left(A G M P^{ \pm}\right)+\left(S E D^{ \pm}\right)\left(S E M P^{ \pm}\right)\right]\right. \\
& \left.+\frac{1}{p^{ \pm}}\left(P W S T^{ \pm}\right)\left(P W S D^{ \pm}\right)\left(W S C^{ \pm}\right)\left[\sum_{j=1}^{m}\left(I N D_{j}^{ \pm}\right)\left(I N M P_{j}^{ \pm}\right)+\left(A G D^{ \pm}\right)\left(A G M P^{ \pm}\right)+\left(S E D^{ \pm}\right)\left(S E M P^{ \pm}\right)\right]\right\} \\
\max P= & \frac{1}{p^{ \pm}}\left[\sum_{j=1}^{m}\left(I N D_{j}^{ \pm}\right)\left(I N M P_{j}^{ \pm}\right)+\left(A G D^{ \pm}\right)\left(A G M P^{ \pm}\right)+\left(S E M P^{ \pm}\right)\left(S E D^{ \pm}\right)\right]
\end{aligned}
$$

where:

- $\mathrm{IND}_{\mathrm{j}}^{ \pm}$(endogenous variable): the added value of industry $\mathrm{j}$ of the secondary sector (10 thousand RMB Yuan/a);

- $\mathrm{AGD}^{ \pm}$(endogenous variable): the added value of the primary sector (10 thousand RMB Yuan/a);

- $\operatorname{SED}^{ \pm}$(endogenous variable): the added value of the tertiary sector (10 thousand RMB Yuan/a); 
- $\mathrm{WWC}^{ \pm}$: unit cost of wastewater treatment (10 thousand RMB Yuan/ton);

- $\operatorname{INWWT}_{\mathrm{j}}^{ \pm}$: wastewater treatment rate of industry $\mathrm{j}(\%)$;

- $\mathrm{AGWWT}^{ \pm}$: wastewater treatment rate of the primary sector $(\%)$;

- $\mathrm{SEWWT}^{ \pm}$: wastewater treatment rate of the tertiary sector $(\%)$;

- $\mathrm{PWWT}^{ \pm}$: domestic wastewater treatment rate (\%);

- $I_{W W W D}^{ \pm}$: wastewater emission per unit output value of industry $\mathrm{j}$ (ton/10 thousand RMB Yuan);

- AGWWD ${ }^{ \pm}$: wastewater emission per unit output value of the primary sector (ton/10 thousand RMB Yuan);

- $\mathrm{SEWWD}^{ \pm}$: wastewater emission per unit output value of the tertiary sector (ton/10 thousand RMB Yuan);

- $\mathrm{PWWD}^{ \pm}$: annual sewage discharge per capita (ton/person);

- INWSD $_{\mathrm{j}}^{ \pm}$: solid waste emission per unit output value of industry $\mathrm{j}$ (ton/10 thousand RMB Yuan);

- $\mathrm{AGWSD}^{ \pm}$: solid waste emission per unit output value of the primary sector (ton/10 thousand RMB Yuan);

- $\mathrm{SEWSD}^{ \pm}$: solid waste emission per unit output value of the tertiary sector (ton/10 thousand RMB Yuan);

- $\mathrm{PWSD}^{ \pm}$: annual solid waste emission per capita (ton/person);

- $\mathrm{INWST}_{\mathrm{j}}^{ \pm}$: solid waste treatment rate of industry $\mathrm{j}(\%)$;

- $\mathrm{AGWST}^{ \pm}$: solid waste treatment rate of the primary sector $(\%)$;

- $\mathrm{SEWST}^{ \pm}$: solid waste treatment rate of the tertiary sector $(\%)$;

- $\mathrm{PWST}^{ \pm}$: garbage disposal rate (\%);

- $\mathrm{WSC}^{ \pm}$: unit cost of solid waste treatment (10 thousand RMB Yuan/ton);

- $\mathrm{INMP}_{\mathrm{j}}^{ \pm}$: the number of employees per unit output value of industry $\mathrm{j}$ (person/10 thousand RMB Yuan);

- $\mathrm{AGMP}^{ \pm}$: the number of employees per unit output value of the primary sector (person/10 thousand RMB Yuan);

- $\mathrm{SEMP}^{ \pm}$: the number of employees per unit output value of the tertiary sector (person/10 thousand RMB Yuan);

- $\mathrm{p}^{ \pm}$: the ratio of employment $(\%)$.

\subsection{Constraints}

The constraints include the water environmental capacity, water resources, atmospheric environmental capacity, energy, economic and nonnegative constraints. The water environmental capacity constraints include $\mathrm{COD}$ and $\mathrm{NH}_{3}-\mathrm{N}$ constraints. The economic constraints refer to industrial output value constraints based on the Tongzhou new town plan.

\subsubsection{Water Environmental Capacity Constraint}

(1) COD emission constraint: The COD emissions from production and living should be within the limits of the environmental capacity of COD. The production COD emissions consist of primary, secondary and tertiary sector COD emissions. 
$\sum_{j=1}^{m}\left(I N C O D_{j}^{ \pm}\right)\left(I N D_{j}^{ \pm}\right)\left(1-\left(I N W W T_{j}^{ \pm}\right)\left(R E M C O D^{ \pm}\right)\right)+\sum_{j=1}^{m} \frac{1}{p^{ \pm}}\left(P C O D_{j}^{ \pm}\right)\left(I N M P_{j}^{ \pm}\right)\left(I N D_{j}^{ \pm}\right)\left(1-\left(P W W T^{ \pm}\right)\left(R E M C O D^{ \pm}\right)\right)$

$+\left(A G C O D^{ \pm}\right)\left(A G D^{ \pm}\right)\left(1-\left(A G W W T^{ \pm}\right)\left(R E M C O D^{ \pm}\right)\right)+\frac{1}{p^{ \pm}}\left(P C O D^{ \pm}\right)\left(A G M P_{j}^{ \pm}\right)\left(A G D^{ \pm}\right)\left(1-\left(P W W T^{ \pm}\right)\left(R E M C O D^{ \pm}\right)\right)$

$+\left(S E C O D^{ \pm}\right)\left(S E D^{ \pm}\right)\left(1-\left(S E W W T^{ \pm}\right)\left(R E M C O D^{ \pm}\right)\right)+\frac{1}{p^{ \pm}}\left(P C O D^{ \pm}\right)\left(S E M P_{j}^{ \pm}\right)\left(S E D^{ \pm}\right)\left(1-\left(P W W T^{ \pm}\right)\left(R E M C O D^{ \pm}\right)\right)$

$\leq C A P C O D^{ \pm}$

(2) $\mathrm{NH}_{3}-\mathrm{N}$ emission constraint: The $\mathrm{NH}_{3}-\mathrm{N}$ emissions from production and living should be within the limits of the environmental capacity of $\mathrm{NH}_{3}-\mathrm{N}$. The production $\mathrm{NH}_{3}-\mathrm{N}$ emissions consist of primary, secondary and tertiary sector $\mathrm{NH}_{3}-\mathrm{N}$ emissions.

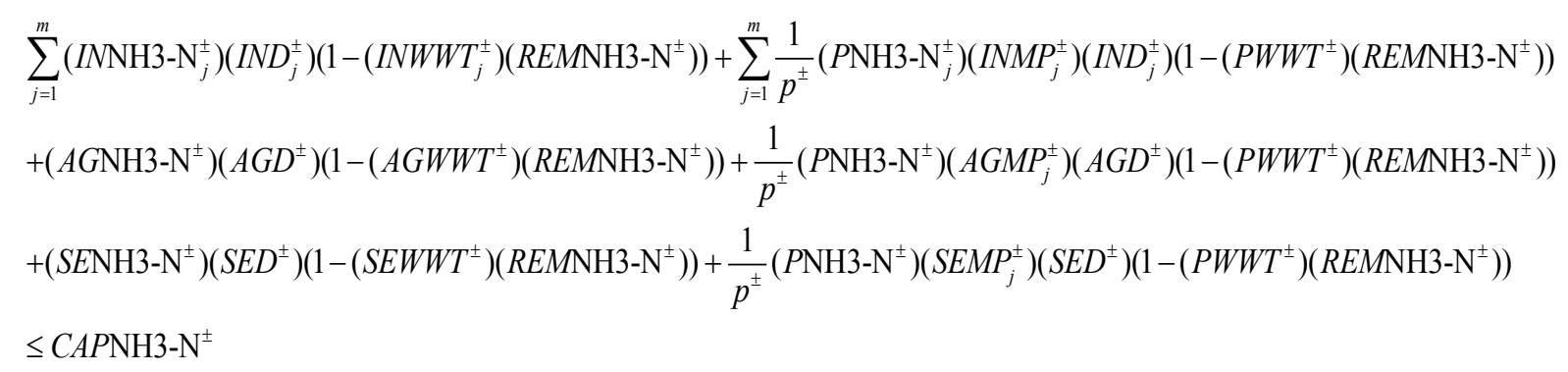

\subsubsection{Water Resource Constraint}

The water consumption of production and living should not exceed the water supply. The production water consumption consists of primary, secondary and tertiary sector water consumption.

$$
\begin{aligned}
& \sum_{j=1}^{m}\left(I N W D_{j}^{ \pm}+\frac{1}{p^{ \pm}}\left(P W D_{j}^{ \pm}\right)\left(I N M P_{j}^{ \pm}\right)\right)\left(I N D_{j}^{ \pm}\right)+\left(A G W D^{ \pm}+\frac{1}{p^{ \pm}}\left(P W D^{ \pm}\right)\left(A G M P^{ \pm}\right)\right)\left(A G D^{ \pm}\right) \\
& +\left(S E W D^{ \pm}+\frac{1}{p^{ \pm}}\left(P W D^{ \pm}\right)\left(S E M P^{ \pm}\right)\right)\left(S E D^{ \pm}\right) \leq M A X W^{ \pm}
\end{aligned}
$$

\subsubsection{Atmospheric Environmental Capacity Constraints}

The $\mathrm{SO}_{2}$ emissions from production and living should be within the limits of the environmental capacity of $\mathrm{SO}_{2}$. The production $\mathrm{SO}_{2}$ emissions consist of primary, secondary and tertiary sector $\mathrm{SO}_{2}$ emissions.

$$
\begin{aligned}
& \sum_{j=1}^{m}\left(I N S O_{2 j}^{ \pm}+\frac{1}{p^{ \pm}}\left(P_{S O}{ }_{2}^{ \pm}\right)\left(I N M P_{j}^{ \pm}\right)\right)\left(I N D_{j}^{ \pm}\right)+\left(A G S O_{2}^{ \pm}+\frac{1}{p^{ \pm}}\left(P S O_{2}^{ \pm}\right)\left(A G M P_{j}^{ \pm}\right)\right)\left(A G D^{ \pm}\right) \\
& +\left(\operatorname{SESO}_{2}^{ \pm}+\frac{1}{p^{ \pm}}\left(\text {PSO }_{2}^{ \pm}\right)\left(S E M P_{j}^{ \pm}\right)\right)\left(S E D^{ \pm}\right) \leq \text {CAPSO }_{2}^{ \pm}
\end{aligned}
$$

\subsubsection{Energy Constraint}

The energy consumption of production and living should not exceed the energy supply. The production energy consumption consists of primary, secondary and tertiary sector energy consumption. 


$$
\begin{aligned}
& \sum_{j=1}^{m}\left(I N G D_{j}^{ \pm}+\frac{1}{p^{ \pm}}\left(P G D_{j}^{ \pm}\right)\left(I N M P_{j}^{ \pm}\right)\right)\left(I N D_{j}^{ \pm}\right)+\left(A G G D^{ \pm}+\frac{1}{p^{ \pm}}\left(P G D^{ \pm}\right)\left(A G M P^{ \pm}\right)\right)\left(A G D^{ \pm}\right)+\left(S E G D^{ \pm}\right. \\
& \left.+\frac{1}{p^{ \pm}}\left(P G D^{ \pm}\right)\left(S E M P^{ \pm}\right)\right)\left(S E D^{ \pm}\right) \leq M A X G^{ \pm}
\end{aligned}
$$

\subsubsection{Economic Constraints}

The development of every industry should be within a certain scope based on the Tongzhou new town plan.

$$
U_{G D P j} \geq I N D_{\mathrm{j}} \geq L_{G D P j} ; \quad U_{G D P 1} \geq A G D \geq L_{G D P 1} ; \quad U_{G D P 3} \geq S E D \geq L_{G D P 3}
$$

3.3.6. Non-Negative Constraints

$$
I N D_{j}^{ \pm} \geq 0 ; A G D^{ \pm} \geq 0 ; S E D^{ \pm} \geq 0 ; W W M_{k}^{ \pm} \geq 0
$$

where:

- $\mathrm{AGCOD}^{ \pm}$: COD emission per unit output value of the primary sector (ton/10 thousand RMB Yuan);

- $\mathrm{AGNH}_{3}-\mathrm{N}^{ \pm}: \mathrm{NH}_{3}-\mathrm{N}$ emission per unit output value of the primary sector (ton/10 thousand RMB Yuan);

- $\mathrm{AGSO}_{2}{ }^{ \pm}: \mathrm{SO}_{2}$ emission per unit output value of the primary sector (ton/10 thousand RMB Yuan);

- $\mathrm{INCOD}_{\mathrm{j}}^{ \pm}$: COD emission per unit output value of industry $\mathrm{j}$ (ton/10 thousand RMB Yuan);

- $\mathrm{INNH}_{3}-\mathrm{N}_{\mathrm{j}}^{ \pm}: \mathrm{NH}_{3}-\mathrm{N}$ emission per unit output value of industry $\mathrm{j}$ (ton/10 thousand RMB Yuan);

- $\mathrm{INSO}_{2 \mathrm{j}}{ }^{ \pm}: \mathrm{SO}_{2}$ emission per unit output value of industry $\mathrm{j}$ (ton/10 thousand RMB Yuan);

- $\mathrm{SECOD}^{ \pm}$: COD emission per unit output value of the tertiary sector (ton/10 thousand RMB Yuan);

- $\mathrm{SENH}_{3}-\mathrm{N}^{ \pm}: \mathrm{NH}_{3}-\mathrm{N}$ emission per unit output value of the tertiary sector (ton/10 thousand RMB Yuan);

- $\mathrm{SESO}_{2}{ }^{ \pm}: \mathrm{SO}_{2}$ emission per unit output value of the tertiary sector (ton/10 thousand RMB Yuan);

- $\mathrm{PCOD}^{ \pm}$: annual COD discharge per capita (ton/person);

- $\mathrm{PNH}_{3}-\mathrm{N}^{ \pm}$: annual $\mathrm{NH}_{3}-\mathrm{N}$ discharge per capita (ton/person);

- $\mathrm{PSO}_{2}{ }^{ \pm}$: annual $\mathrm{SO}_{2}$ discharge per capita (ton/person);

- $\mathrm{REMCOD}^{ \pm}$: COD removal rate of sewage treatment plant $(\%)$;

- $\mathrm{REMNH}_{3}-\mathrm{N}^{ \pm}: \mathrm{NH}_{3}-\mathrm{N}$ removal rate of sewage treatment plant (\%);

- $\mathrm{CAPCOD}^{ \pm}$: environmental capacity of COD (ton/a);

- $\mathrm{CAPNH}_{3}-\mathrm{N}^{ \pm}$: environmental capacity of $\mathrm{NH}_{3}-\mathrm{N}$ (ton/a);

- $\mathrm{CAPSO}_{2}{ }^{ \pm}$: environmental capacity of $\mathrm{SO}_{2}$ (ton/a);

- $\mathrm{INWD}_{\mathrm{j}}^{ \pm}$: water demand per unit output value of industry $\mathrm{j}$ (ton/10 thousand RMB Yuan);

- $A G W D^{ \pm}$: water demand per unit output value of the primary sector (ton/10 thousand RMB Yuan);

- $\mathrm{SEWD}^{ \pm}$: water demand per unit output value of the tertiary sector (ton/10 thousand RMB Yuan);

- $\mathrm{PWD}^{ \pm}$: water demand per capita (ton/person);

- $\mathrm{MAXW}^{ \pm}$: water supply (ton/a);

- INGD $^{ \pm}$: energy demand per unit output value of industry j (tce/10 thousand RMB Yuan);

- $P G D^{ \pm}$: energy demand per capita (tce/person);

- $\mathrm{AGGD}^{ \pm}$: energy demand per unit output value of the primary sector (tce/10 thousand RMB Yuan);

- $\mathrm{SEGD}^{ \pm}$: energy demand per unit output value of the tertiary sector (tce/10 thousand RMB Yuan); 
- $\mathrm{MAXG}^{ \pm}$energy supply (tce/a);

- $\mathrm{U}_{\mathrm{GDPJ}}$ : the added value upper limit of industry $\mathrm{j}$ of the secondary sector (10 thousand RMB Yuan);

- $\mathrm{L}_{\mathrm{GDPJ}}$ : the added value lower limit of industry $\mathrm{j}$ of the secondary sector (10 thousand RMB Yuan);

- $\mathrm{U}_{\mathrm{GDP} 1}$ : the added value upper limit of the primary sector (10 thousand RMB Yuan);

- $\mathrm{L}_{\mathrm{GDP} 1}$ : the added value lower limit of the primary sector (10 thousand RMB Yuan);

- $\mathrm{U}_{\mathrm{GDP} 3}$ : the added value upper limit of the tertiary sector (10 thousand RMB Yuan);

- $\mathrm{L}_{\mathrm{GDP} 3}$ : the added value lower limit of the tertiary sector (10 thousand RMB Yuan);

\section{Study Area and Data Sources}

\subsection{Site Description}

Tongzhou District is located in the southeast part of Beijing. The district is approximately $37 \mathrm{~km}$ wide from east to west and $48 \mathrm{~km}$ long from north to south. It has an area of approximately $906 \mathrm{~km}^{2}$, which comprises approximately $5 \%$ of Beijing's total territory and approximately $14 \%$ of Beijing's plain. It is busily remodeling itself as a modern city.

\subsection{Data Sources}

The selected values of many parameters are based on the strategic environmental impact assessment in Tongzhou District. Specifically, the $\mathrm{COD}$ and $\mathrm{NH}_{3}-\mathrm{N}$ pollution emissions per unit output value of industry data are calculated by environmental statistics of Tongzhou District (2001-2010), Tongzhou statistical yearbook (2000-2010) and the 12th Five-Year Plan of social economy development of Tongzhou District. Domestic wastewater treatment rate data are from the Beijing city general plan (2004-2020). Solid waste treatment rate of industry data are from technology development planning. Energy supply data are from Tongzhou new town plan (2005-2020). Energy demand per unit output value of industry data are from industry development planning (2006-2010). Annual sewage discharge per capita data are from the pollution discharge declaration of Tongzhou District (2001-2010). Annual solid waste emission per capita data are from environmental protection and ecological construction planning. Garbage disposal rate data are from the special plan for environmental protection and ecological construction.

\section{Scenario Establishment}

In Scenario 1 (the business as usual scenario [36]), the level of production technology remains in accord with the current trends. Scenario 2 (the sustainable development scenario [36]) is an idealized scenario in which the pressures of the environment and water and energy shortages are reduced through upgrades in production technology and pollution prevention technology in the planning objective. There are two time points (2015 and 2020) in the analysis under the two scenarios, and they are independent of each other.

The most important parameters of the two scenarios are listed below (Table 1). The model consists of the primary sector (I12), secondary sector and tertiary sector (I13). The secondary sector includes 11 industries: equipment manufacturing (I01), including general equipment manufacturing, special equipment manufacturing, transportation equipment manufacturing, electric equipment and machinery 
manufacturing, communication equipment manufacturing and other electronic equipment manufacturing; textile and garments (I02), including textile and clothing; food processing (I03); printing, culture and education (I04); wood furniture (I05); craft manufacturing (I06); pharmaceuticals (I07); petrochemicals (I08); papermaking (I09); others (I10), including mining, chemical fiber manufacturing, rubber and plastic products, non-metallic mineral products, non-ferrous metal processing and metal processing; and construction (I11).

Table 1. The important parameters of the environmental resource constraints.

\begin{tabular}{lccccc}
\hline \multirow{2}{*}{ Items } & \multicolumn{2}{c}{$\mathbf{2 0 1 5}$} & & \multicolumn{2}{c}{$\mathbf{2 0 2 0}$} \\
\cline { 2 - 3 } \cline { 5 - 6 } \cline { 5 - 6 } & Lower limits & Upper limits & & Lower limits & Upper limits \\
\hline $\mathrm{CAPCOD}^{ \pm}$(tons) & 3558.06 & 3558.06 & & 3558.06 & 3558.06 \\
$\mathrm{CAPSO}_{2}{ }^{ \pm}$(tons) & 34,520 & 41,311 & & 34,520 & 41,311 \\
$\mathrm{CAPNH}_{3}-\mathrm{N}^{ \pm}$(tons) & 351 & 429 & & 315 & 385 \\
$\mathrm{MAXW}^{ \pm}(10,000$ tons) & $45,057.2$ & $60,960.0$ & & $48,587.7$ & $65,736.3$ \\
$\mathrm{MAXG}^{ \pm}(10,000$ tce) & 407.4 & 456.8 & & 576.2 & 640.2 \\
\hline
\end{tabular}

\section{Results and Discussion}

\subsection{Industry Scale and Structure}

From the results in Figure 1, it is apparent that the industrial structures are significantly different under the two scenarios. In Scenario 1, the equipment manufacturing industry is the leading sector in both 2015 and 2020. In Scenario 2, the equipment manufacturing industry, construction industry, textile and garments industry, food processing industry and printing, culture and education industry are expected to be the predominant industries in 2015 and 2020 as a result of the adjustment of the industrial structure.

\section{(1) Equipment manufacturing industry I01}

The equipment manufacturing industry has the second-lowest COD emission, second only to that of the construction industry, making it suitable for development in Tongzhou District.

Equipment manufacturing is the leading industry, with the highest GDP out of the 10 other industries currently in Tongzhou District, and demonstrates a good foundation and strong potential. Although the equipment manufacturing industry shows certain growth in both scenarios, it shows faster development in Scenario 2. The industry added value is 3.03-4.00 million RMB Yuan in 2020 under Scenario 2 and 1.10-1.10 million RMB Yuan in 2020 in Scenario 1. This is a result of the equipment manufacturing industry having lower energy consumption and pollutant emissions per unit of output value in Scenario 2.

(2) Textile and garments industry I02

The textile industry has a higher energy consumption, a higher water consumption, higher pollutant emissions and a higher input-output ratio. However, the clothing industry is a green industry with less pollution, lower energy consumption and lower material consumption. The results illustrate that the growth of the textile and garments industry is limited for the relatively low technology level in Scenario 1. The industry added values are 0.09-0.10 and 0.19-0.19 million RMB Yuan in 2015 and 2020, respectively. Fortunately, because of the improvements in production techniques and pollution 
prevention technology, the discharge of major pollutants can be effectively controlled in Scenario 2. In Scenario 2, the industry added values are $0.40-1.50$ and 1.00-1.50 million RMB Yuan in 2015 and 2020, respectively. Additionally, because the textile and garments industry is an "urban industry" that closely relates to people's lives, it is one of the leading industries in Tongzhou District in Scenario 2.

(3) Food processing industry I03

The food processing industry is the second highest emitter of COD per unit GDP, after the paper making industry. Therefore, its development should not proceed too rapidly in Scenario 1. However, demand for high quality food increases as time progresses and society advances; thus, the food processing industry is an essential industry. Specifically, it shows more rapid growth in Scenario 2, mainly due to the improved pollution control. The added value of the food processing industry increases to $0.90-1.50$ million RMB Yuan in 2020 in Scenario 2.

(4) Printing, culture and education industry I04

The printing, culture and education industry has relatively low water consumption and COD emissions per unit output value. However, because Tongzhou District is located on the outskirts of Beijing, the printing, culture and education industry is small and currently has a low market share. As the results demonstrate, the growth of the printing, culture and education industry is very slow in Scenario 1, with 0.10-0.15 million RMB Yuan in 2015 and 0.20-0.20 million RMB Yuan in 2020. In Scenario 2, there are efforts to introduce advanced foreign technology to effectively cultivate core technology innovation, which improves the overall quality of the printing, culture and education industry during the current 12th Five-Year Plan This provides strong support for the printing, culture and education industry's future advancement. Therefore, it has a faster improvement pace in 2015 and 2020 in Scenario 2 where the industry added value is $0.15-0.50$ and $0.50-1.00$ million RMB Yuan, respectively.

(5) Wood furniture industry I05

The wood furniture industry is a relatively clean industry, and the water consumption and COD emissions per unit output are relatively small. Tongzhou District has a serious lack of water resources, making it suitable for the development of the wood furniture industry. The industry added value is 0.50-0.80 million RMB Yuan in 2020 under Scenario 1.

(6) Craft manufacturing industry I06

Craft manufacturing consumes much energy and releases many pollutants from production. The scale of the craft manufacturing industry should be limited in Tongzhou District. As shown in Figure 1, the GDP of the craft manufacturing industry is low in both scenarios, and the added value is $0.04-0.04$ and 0.10-0.20 million RMB Yuan in Scenarios 1 and 2, respectively, in 2020.

(7) Pharmaceutical industry I07

The pharmaceutical industry brings much pressure on environmental protection. Because it is affected by pollution, the pharmaceutical industry develops slowly and is proportionally small in Tongzhou's economy. In Scenario 2, low emission technology is developed, and the added value of pharmaceutical industry is $0.05-0.10$ million RMB Yuan in 2020, which is a little higher than that in Scenario 1 . However, the size of the industry does not show a substantial change in 2015 and 2020 under the two scenarios. 
(8) Petrochemical industry I08

The petrochemical industry is the main pillar of industry in Tongzhou District and should have been a top priority. However, the results show that this industry has barely developed recently. The petrochemical industry causes significant water and air pollution. There is little space for further growth in Scenario 1 because of limited water and air environmental capacity. Due to the improvement of pollution control technology under Scenario 2, the petrochemical industry experiences an increase under the allowed conditions of water and atmosphere environmental capacity. The added value is $0.04-0.10$ million RMB Yuan in 2020.

(9) Papermaking industry I09

The papermaking industry is a major water polluting industry in China, and water pollution in Tongzhou District is especially severe. Thus, the papermaking industry is not suitable for further development in the district under the two scenarios.

(10) Others I10

The industry added value is $0.07-0.07$ and $0.09-0.19$ million RMB Yuan in 2020 under Scenarios 1 and 2, respectively. Thus, these other industries are not suitable for large growth in Tongzhou District.

(11) Construction industry I11

The construction industry consumes little energy and water and results in low $\mathrm{COD}$ and $\mathrm{SO}_{2}$ emissions. Because Tongzhou is short of water resources, the growth of the construction industry should be given priority.

Figure 1. The added values of the 11 industries (a) in 2015 in Scenario 1, (b) in 2020 in Scenario 1, (c) in 2015 in Scenario 2, (d) in 2020 in Scenario 2.

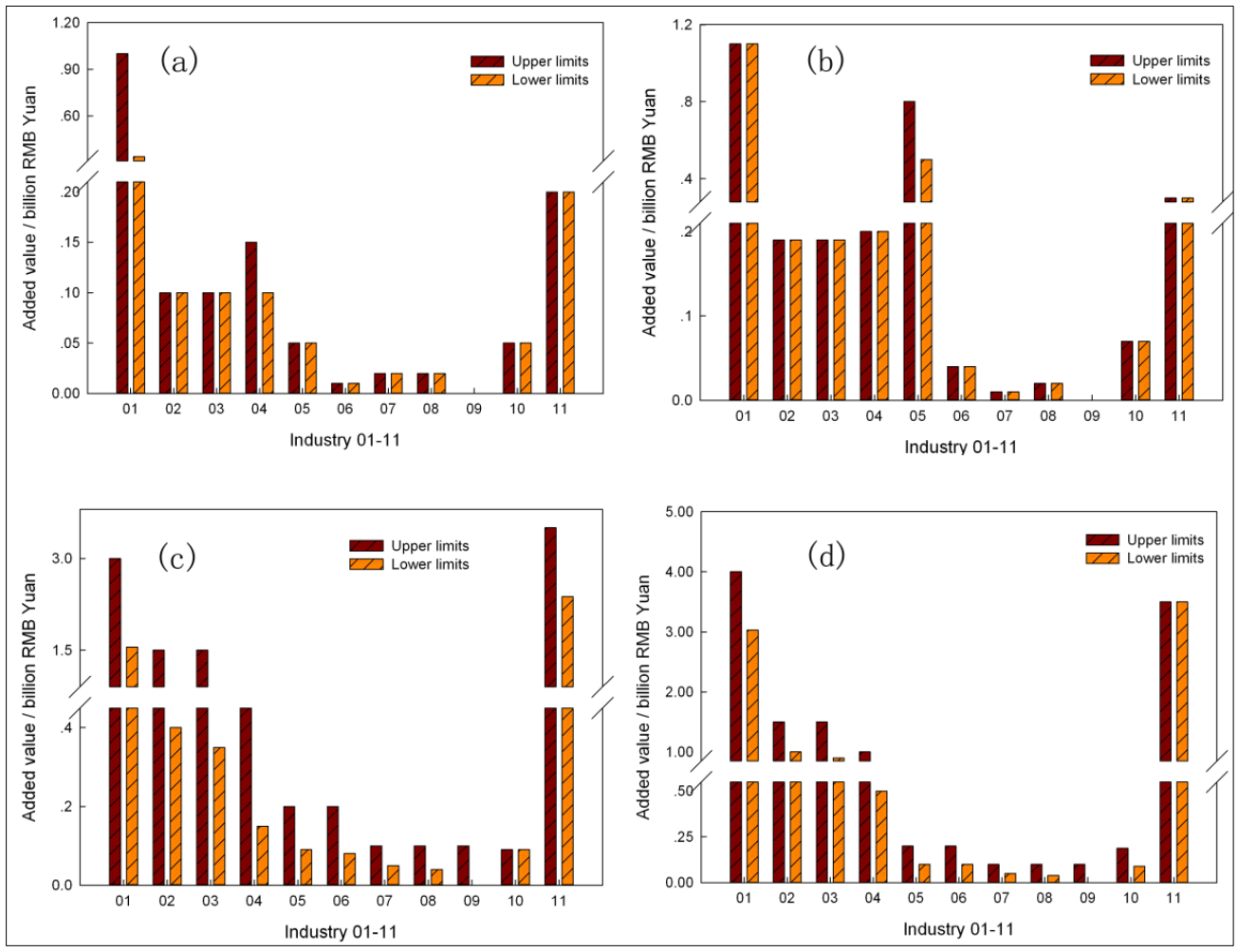


As Figure 1 demonstrates, the construction industry has become one of the leading industries in Tongzhou District. Its added value is 2.37-3.50 and 3.50-3.50 million RMB Yuan in 2015 and 2020, respectively, under Scenario 2.

\subsection{Economic Development Scale}

As shown in Table 2, Tongzhou District's GDP will reach 1.79-3.72 billion RMB Yuan in 2015 and 3.43-7.15 billion RMB Yuan in 2020 in Scenario 1. Table 3 shows that the GDP of Tongzhou District will reach 8.57-19.39 billion RMB Yuan in 2015 and 16.11-47.82 billion RMB Yuan in 2020. The ratios of primary and secondary sectors decrease; however, the ratio of the tertiary sector increases in 2020 in Scenario 2. The economic goals (120 billion RMB Yuan) in the Tongzhou new town plan cannot be achieved in both scenarios.

Table 2. The Gross Domestic Product (GDP) of three industries in Scenario 1.

\begin{tabular}{|c|c|c|c|c|c|c|}
\hline & \multicolumn{3}{|c|}{2015} & \multicolumn{3}{|c|}{2020} \\
\hline & $\begin{array}{l}\text { Upper limits } \\
\text { (billion } \\
\text { RMB Yuan) }\end{array}$ & $\begin{array}{c}\text { Lower limits } \\
\text { (billion } \\
\text { RMB Yuan) }\end{array}$ & $\begin{array}{c}\text { Percentage } \\
(\%)\end{array}$ & $\begin{array}{l}\text { Upper limits } \\
\text { (billion } \\
\text { RMB Yuan) }\end{array}$ & $\begin{array}{c}\text { Lower limits } \\
\text { (billion } \\
\text { RMB Yuan) }\end{array}$ & $\begin{array}{c}\text { Percentage } \\
(\%)\end{array}$ \\
\hline Primary sector & 0.20 & 0.20 & $5-11$ & 0.20 & 0.20 & $3-6$ \\
\hline Secondary sector & 1.70 & 0.99 & $46-55$ & 2.92 & 2.62 & $41-76$ \\
\hline Tertiary sector & 1.82 & 0.60 & $34-49$ & 4.03 & 0.61 & $18-56$ \\
\hline Tongzhou's GDP & 3.72 & 1.79 & & 7.15 & 3.43 & \\
\hline
\end{tabular}

Table 3. The GDP of three industries in Scenario 2.

\begin{tabular}{|c|c|c|c|c|c|c|}
\hline & \multicolumn{3}{|c|}{2015} & \multicolumn{3}{|c|}{2020} \\
\hline & $\begin{array}{c}\text { Upper limits } \\
\text { (billion } \\
\text { RMB Yuan) }\end{array}$ & $\begin{array}{c}\text { Lower limits } \\
\text { (billion } \\
\text { RMB Yuan) }\end{array}$ & $\begin{array}{c}\text { Percentage } \\
(\%)\end{array}$ & $\begin{array}{c}\text { Upper limits } \\
\text { (billion } \\
\text { RMB Yuan) }\end{array}$ & $\begin{array}{c}\text { Lower limits } \\
\text { (billion } \\
\text { RMB Yuan) }\end{array}$ & $\begin{array}{c}\text { Percentage } \\
(\%)\end{array}$ \\
\hline Primary sector & 0.40 & 0.40 & $2-5$ & 0.70 & 0.70 & $1-4$ \\
\hline Secondary sector & 10.79 & 5.17 & $56-60$ & 12.39 & 9.31 & $26-58$ \\
\hline Tertiary sector & 8.20 & 3.00 & $35-42$ & 34.74 & 6.10 & $38-73$ \\
\hline Tongzhou's GDP & 19.39 & 8.57 & & 47.82 & 16.11 & \\
\hline
\end{tabular}

\subsection{Population Size}

As the optimization results show in Tables 4 and 5, the appropriate working population sizes in Tongzhou District in 2015 and 2020 are $0.10-0.20$ and $0.13-0.28$ million people in Scenario 1 and $0.30-0.72$ and $0.38-1.38$ million people in Scenario 2. According to the new town plan, the planned working population sizes are 0.9 and 1.5 million people in 2015 and 2020, respectively. In either scenario, the environmental and energy conditions in Tongzhou District cannot accommodate the population size reaching its planned target.

The future distribution of the working population in various industries is shown in Tables 4 and 5 . The secondary sector has the highest demand for labor in Scenario 1, and the labor demand proportions of the primary and tertiary industries are not changed significantly. In Scenario 2, the proportion of the 
workforce in the tertiary sector rises sharply, whereas the proportion of the workforce in the secondary sector declines in 2020. The primary sector requires the smallest working population in the two scenarios and requires a greater working population in Scenario 2 than in Scenario 1.

Table 4. The population size of three industries in Scenario 1.

\begin{tabular}{|c|c|c|c|c|c|c|}
\hline & \multicolumn{3}{|c|}{2015} & \multicolumn{3}{|c|}{2020} \\
\hline & $\begin{array}{c}\text { Upper limits } \\
\text { (thousand } \\
\text { persons) } \\
\end{array}$ & $\begin{array}{c}\text { Lower limits } \\
\text { (thousand } \\
\text { persons) } \\
\end{array}$ & $\begin{array}{c}\text { Percentage } \\
(\%)\end{array}$ & $\begin{array}{c}\text { Upper limits } \\
\text { (thousand } \\
\text { persons) } \\
\end{array}$ & $\begin{array}{c}\text { Lower limits } \\
\text { (thousand } \\
\text { persons) } \\
\end{array}$ & $\begin{array}{c}\text { Percentage } \\
(\%)\end{array}$ \\
\hline Primary sector & 29.45 & 27.15 & $15-27$ & 23.15 & 22.17 & $8-17$ \\
\hline Secondary sector & 89.84 & 50.78 & $46-50$ & 126.29 & 91.40 & $44-69$ \\
\hline Tertiary sector & 77.16 & 22.78 & $23-39$ & 134.18 & 18.28 & $14-47$ \\
\hline Total working population & 196.46 & 100.71 & & 283.63 & 131.85 & \\
\hline
\end{tabular}

Table 5. The population size of three industries in Scenario 2.

\begin{tabular}{cccccccc}
\hline & \multicolumn{3}{c}{$\mathbf{2 0 1 5}$} & & \multicolumn{3}{c}{$\mathbf{2 0 2 0}$} \\
\cline { 2 - 3 } & $\begin{array}{c}\text { Upper limits } \\
\text { (thousand } \\
\text { persons) }\end{array}$ & $\begin{array}{c}\text { Lower limits } \\
\text { (thousand } \\
\text { persons) }\end{array}$ & $\begin{array}{c}\text { Percentage } \\
\mathbf{( \% )}\end{array}$ & $\begin{array}{c}\text { Upper limits } \\
\text { (thousand } \\
\text { persons) }\end{array}$ & $\begin{array}{c}\text { Lower limits } \\
\text { (thousand } \\
\text { persons) }\end{array}$ & $\begin{array}{c}\text { Percentage } \\
\text { (\%) }\end{array}$ \\
\hline Primary sector & 50.91 & 42.31 & $7-14$ & 74.04 & 68.27 & $5-18$ \\
Secondary sector & 383.55 & 167.72 & $53-57$ & & 238.23 & 143.42 & $17-38$ \\
Tertiary sector & 288.91 & 86.55 & $29-40$ & & 1068.90 & 166.39 & $44-78$ \\
Total working population & 723.37 & 296.58 & & & 1381.17 & 378.08 & \\
\hline
\end{tabular}

As shown in Figure 2, the equipment manufacturing industry, the printing, culture and education industry, and the construction industry all need a working population greater than 10,000 in 2015 in Scenario 1. Until 2020, these three industries, particularly the construction industry, as well as the wood furniture industry require the largest labor force.

The wood furniture industry and craft manufacturing industry show an upper labor demand of more than 10,000 workers in 2015 in Scenario 2. In addition, the upper demand of the labor force of the equipment manufacturing industry, the textile and garments industry, the food processing industry, the printing, culture and education industry, and the construction industry are more than 20,000 workers in 2015. However, by 2020, most of the industries of the secondary sector will generally need a smaller workforce than they will need in 2015.

According to the above results, the three sectoral productivities can be obtained in Table 6 . The productivities of the three sectors will reach 8.64-9.02, 23.12-28.67 and 30.03-33.37 thousand RMB Yuan/person in 2020 in Scenario 1, respectively, and the productivity of the tertiary sector will be highest in Scenario 1. The three sectoral productivities in Scenario 2 will be higher than those in Scenario 1, and will reach 9.45-10.25, 52.01-64.91 and 32.50-36.66 thousand RMB Yuan/person in 2020. Specifically, the secondary sector's productivity will be highest in 2020 in Scenario 2 . That is mainly due to the fact that most of the industries of the secondary sector will generally need a smaller workforce with the application of science and technology. 
Figure 2. The population size of 11 industries (a) in 2015 in Scenario 1, (b) in 2020 in Scenario 1, (c) in 2015 in Scenario 2, (d) in 2020 in Scenario 2.
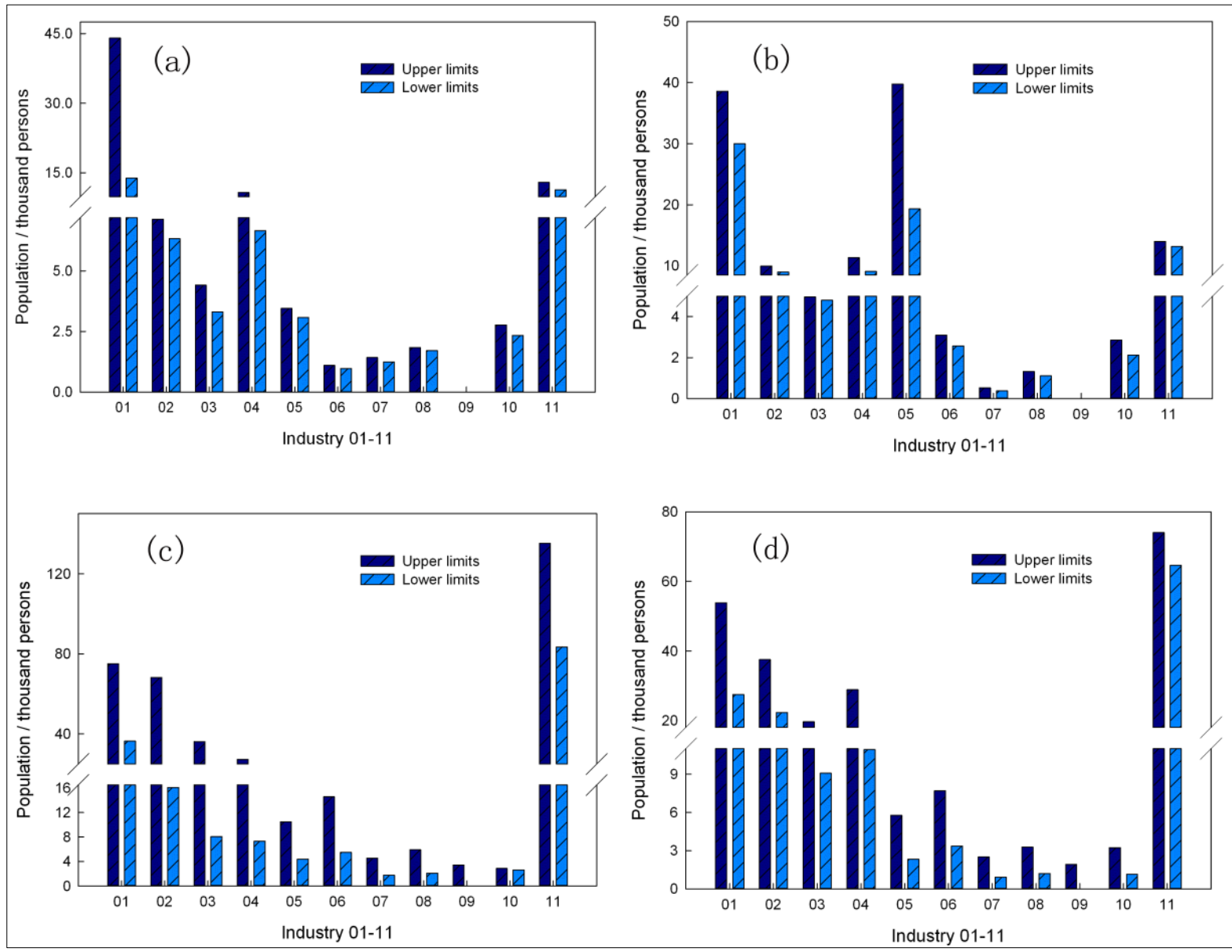

Table 6. The productivities of three industries.

\begin{tabular}{|c|c|c|c|c|c|c|c|c|}
\hline & \multicolumn{4}{|c|}{$\begin{array}{c}\text { Scenario } 1 \text { (thousand RMB } \\
\text { Yuan/person) }\end{array}$} & \multicolumn{4}{|c|}{$\begin{array}{c}\text { Scenario } 2 \text { (thousand RMB } \\
\text { Yuan/person) }\end{array}$} \\
\hline & \multicolumn{2}{|c|}{2015} & \multicolumn{2}{|c|}{2020} & \multicolumn{2}{|c|}{2015} & \multicolumn{2}{|c|}{2020} \\
\hline & $\begin{array}{l}\text { Upper } \\
\text { limits }\end{array}$ & $\begin{array}{l}\text { Lower } \\
\text { limits }\end{array}$ & $\begin{array}{l}\text { Upper } \\
\text { limits }\end{array}$ & $\begin{array}{l}\text { Lower } \\
\text { limits }\end{array}$ & $\begin{array}{l}\text { Upper } \\
\text { limits }\end{array}$ & $\begin{array}{l}\text { Lower } \\
\text { limits }\end{array}$ & $\begin{array}{l}\text { Upper } \\
\text { limits }\end{array}$ & $\begin{array}{l}\text { Lower } \\
\text { limits }\end{array}$ \\
\hline Primary sector & 7.37 & 6.79 & 9.02 & 8.64 & 9.45 & 7.86 & 10.25 & 9.45 \\
\hline Secondary sector & 19.50 & 18.92 & 28.67 & 23.12 & 30.83 & 28.13 & 64.91 & 52.01 \\
\hline Tertiary sector & 26.34 & 23.59 & 33.37 & 30.03 & 34.66 & 28.38 & 36.66 & 32.50 \\
\hline Total & 18.94 & 17.77 & 26.01 & 25.21 & 28.90 & 26.81 & 42.61 & 34.62 \\
\hline
\end{tabular}

\section{Conclusions}

In this study, an IFMOP model based on environmental carrying capacity was established to solve the industrial structure optimization problems under multiple uncertainties. IFMOP was developed through incorporation of fuzzy linear programming and inexact linear programming approaches within a general optimization framework, and it could be transformed into two deterministic sub-models corresponding to the lower and upper bounds of the objective. Thus, solutions for the objective function are obtained by solving the sub-models. It improves upon the existing optimization model with advantages in tackling 
dynamic, uncertain and multi-objective characteristics of a variety of system components, and could efficiently deal with industrial structure optimization issues under uncertainties based on environmental carrying capacity level. The model was used to analyze whether the water environmental capacity, water resource supply, atmospheric environmental capacity and energy supply can meet the needs of the planned economic and population development objectives under the business-as-usual scenario and the sustainable development scenario in Tongzhou district.

The results reveal the following: In any scenario, the water resources, energy and environmental conditions in Tongzhou District cannot accommodate the projected economy and population growth. It is necessary to consider changing the target economic growth and population size in the Tongzhou new town plan. The equipment manufacturing industry, textile and garments industry, food processing industry, printing, culture and education industry, and construction industry should be given priority. However, the pharmaceutical industry, petrochemical industry and other industries are not suitable for large scale deployment. The papermaking industry should not be developed any further. The primary sector needs the smallest working population, and the secondary and tertiary sectors require a greater number of workers. The limitations of the study are as follows: it does not take into account the balances of demand and supply in economy and energy and does not consider the interactions among industries in contrast to input-output analysis and applied general equilibrium analysis.

\section{Acknowledgments}

This research was supported by the major science and technology programs of water pollution control and treatment, China (No. 2012ZX07102002-05), by the environmental protection public welfare projects for the research of technological contribution to pollution reduction and the National Action Plan, China (No. 201209037).

\section{Conflicts of interests}

The authors declare no conflict of interest.

\section{References}

1. Figuières, C.; Guyomard, H.; Rotillon, G. Sustainable development: Between moral injunctions and natural constraints. Sustainability 2010, 2, 3608-3622.

2. Bishop, A.B. Carrying Capacity in Regional Environmental Management; United States Environmental Protection Agency: Washington, DC, USA, 1974.

3. Arrow, K.; Bolin, B.; Costanza, R.; Dasgupta, P.; Folke, C.; Holling, C.S.; Jansson, B.O.; Levin, S.; Mäler, K.G.; Perrings, C. Economic growth, carrying capacity, and the environment. Ecol. Econ. 1995, 15, 91-95.

4. Zhang, Y.Y.; Xia, J.; Wang, Z.G. Integrated water resources carrying capacity in Tongzhou district, Beijing city. J. Res. Ecol. 2010, 1, 253-258.

5. Ahmadi, P.; Dincer, I.; Rosen, M.A. Thermodynamic modeling and multi-objective evolutionary-based optimization of a new multigeneration energy system. Energ. Convers. Manag. 2013, 76, 282-300. 
6. Kaviri, A.G.; Jaafar, M.N.M.; Lazim, T.M.; Barzegaravval, H. Exergoenvironmental optimization of heat recovery steam generators in combined cycle power plant through energy and exergy analysis. Energ. Convers. Manag. 2013, 67, 27-33.

7. Ahmadi, P.; Dincer, I.; Rosen, M.A. Performance assessment and optimization of a novel integrated multigeneration system for residential buildings. Energ. Build. 2013, 67, 568-578.

8. Wu, Z.; Xu, J. Predicting and optimization of energy consumption using system dynamics-fuzzy multiple objective programming in world heritage areas. Energy 2013, 49, 19-31.

9. Giannoccaro, I.; Pontrandolfo, P.; Scozzi, B. A fuzzy echelon approach for inventory management in supply chains. Eur. J. Oper. Res. 2003, 149, 185-196.

10. Rong, A.; Lahdelma, R. Fuzzy chance constrained linear programming model for optimizing the scrap charge in steel production. Eur. J. Oper. Res. 2008, 186, 953-964.

11. Petrovic, D.; Roy, R.; Petrovic, R. Supply chain modelling using fuzzy sets. Int. J. Prod. Econ. 1999, 59, 443-453.

12. Salema, M.I.G.; Barbosa-Povoa, A.P.; Novais, A.Q. An optimization model for the design of a capacitated multi-product reverse logistics network with uncertainty. Eur. J. Oper. Res. 2007, 179, 1063-1077.

13. Shahnazari-Shahrezaei, P.; Tavakkoli-Moghaddam, R.; Kazemipoor, H. Solving a multi-objective multi-skilled manpower scheduling model by a fuzzy goal programming approach. Appl. Math. Model. 2013, 37, 5424-5443.

14. Qin, X.S.; Xu, Y. Analyzing urban water supply through an acceptability-index-based interval approach. Adv. Water. Resour. 2011, 34, 873-886.

15. Simic, V.; Dimitrijevic, B. Risk explicit interval linear programming model for long-term planning of vehicle recycling in the EU legislative context under uncertainty. Resour. Conserv. Recy. 2013, $73,197-210$.

16. Dong, C.; Huang, G.; Cai, Y.; Xu, Y. An interval-parameter minimax regret programming approach for power management systems planning under uncertainty. Appl. Energ. 2011, 88, 2835-2845.

17. Sabri, E.H.; Beamon, B.M. A multi-objective approach to simultaneous strategic and operational planning in supply chain design. Omega 2000, 28, 581-598.

18. Shastri, Y.; Diwekar, U. Sensor placement in water networks: A stochastic programming approach. J. Water Resour. Plann. Manag. 2006, 132, 192-203.

19. Guan, Z.; Philpott, A.B. A multistage stochastic programming model for the New Zealand dairy industry. Int. J. Prod. Econ. 2011, 134, 289-299.

20. Ahmed, S.; King, A.J.; Parija, G. A multi-stage stochastic integer programming approach for capacity expansion under uncertainty. J. Global. Optim. 2003, 26, 3-24.

21. Kouwenberg, R. Scenario generation and stochastic programming models for asset liability management. Eur. J. Oper. Res. 2001, 134, 279-292.

22. Gu, J.; Guo, P.; Huang, G.; Shen, N. Optimization of the industrial structure facing sustainable development in resource-based city subjected to water resources under uncertainty. Stoch. Environ. Res. Risk Assess. 2013, 27, 659-673.

23. Li, H.; Zhang, K. Development of a fuzzy-stochastic nonlinear model to incorporate aleatoric and epistemic uncertainty. J. Contam. Hydrol. 2010, 111, 1-12. 
24. Lacagnina, V.; Pecorella, A. A stochastic soft constraints fuzzy model for a portfolio selection problem. Fuzzy Set. Syst. 2006, 157, 1317-1327.

25. Li, P.; Chen, B. Fsilp: Fuzzy-stochastic-interval linear programming for supporting municipal solid waste management. J. Environ. Manag. 2011, 92, 1198-1209.

26. Li, X.M. Study on urban environmental carrying capacity based on an inexact fuzzy multiobjective programming model. Adv. Mater. Res. 2012, 518, 1226-1232.

27. Wu, S.; Huang, G.; Guo, H. An interactive inexact-fuzzy approach for multiobjective planning of water resource systems. Water Sci. Technol. 1997, 36, 235-242.

28. Huang, G.H. IPWM: An interval parameter water quality management model. Eng. Optimiz. 1996, 26, 79-103.

29. Wang, L.; Meng, W.; Guo, H.; Zhang, Z.; Liu, Y.; Fan, Y. An interval fuzzy multiobjective watershed management model for the lake Qionghai watershed, China. Water Resour. Manag. 2006, 20, 701-721.

30. Zou, R.; Guo, H.; Chen, B. A multiobjective approach for integrated environmental economic planning under uncertainty. Civ. Eng. Environ. Syst. 2000, 17, 267-291.

31. Li, Y.F.; Li, Y.P.; Huang, G.H.; Zhou, M.; Xie, Y.L. Modeling for environmental-economic management systems under uncertainty. Procedia Environ. Sci. 2010, 2, 192-198.

32. Dvarioniene, J.; Stasiskiene, Z. Integrated water resource management model for process industry in lithuania. J. Clean. Prod. 2007, 15, 950-957.

33. Shadiya, O.O.; Satish, V.; High, K.A. Process enhancement through waste minimization and multiobjective optimization. J. Clean. Prod. 2012, 31, 137-149.

34. O'Regan, B.; Moles, R. Using system dynamics to model the interaction between environmental and economic factors in the mining industry. J. Clean. Prod. 2006, 14, 689-707.

35. Zhou, M.; Chen, Q.; Cai, Y. Optimizing the industrial structure of a watershed in association with economic-environmental consideration: An inexact fuzzy multi-objective programming model. J. Clean. Prod. 2012, 42, 116-131.

36. Swart, R.J.; Raskin, P.; Robinson, J. The problem of the future: Sustainability science and scenario analysis. Global. Environ. Change 2004, 14, 137-146.

37. Huang, G.; Baetz, B.; Patry, G. Grey fuzzy integer programming: An application to regional waste management planning under uncertainty. Socioecon. Plann. Sci. 1995, 29, 17-38.

38. Guo, H.C. Environmental Planning Methods and Applications; Chemical Industry Press: Beijing, China, 2006. 


\section{Appendix}

Table A1. Important parameters of IFMOP model.

\begin{tabular}{|c|c|c|c|c|c|c|c|c|}
\hline \multirow{3}{*}{ Items } & \multicolumn{4}{|c|}{ Scenario 1} & \multicolumn{4}{|c|}{ Scenario 2} \\
\hline & \multicolumn{2}{|c|}{2015} & \multicolumn{2}{|c|}{2020} & \multicolumn{2}{|c|}{2015} & \multicolumn{2}{|c|}{2020} \\
\hline & Lower limits & Upper limits & Lower limits & Upper limits & Lower limits & Upper limits & Lower limits & Upper limits \\
\hline $\operatorname{REMCOD}^{ \pm}(\%)$ & 0.86 & 0.90 & 0.90 & 0.95 & 0.86 & 0.90 & 0.90 & 0.95 \\
\hline $\operatorname{PCOD}^{ \pm}(\mathrm{kg} /$ people $)$ & 77.20 & 79.20 & 79.20 & 81.20 & 26.00 & 27.00 & 27.00 & 28.00 \\
\hline $\operatorname{PWWT}^{ \pm}(\%)$ & 0.64 & 0.67 & 0.67 & 0.70 & 0.90 & 0.95 & 0.95 & 1.00 \\
\hline $\mathrm{REMNH}_{3}-\mathrm{N}^{ \pm}(\%)$ & 0.92 & 0.92 & 0.92 & 0.92 & 0.92 & 0.92 & 0.92 & 0.93 \\
\hline $\mathrm{PNH}_{3}-\mathrm{N}^{ \pm}(\mathrm{kg} /$ people $)$ & 7.20 & 7.30 & 7.30 & 7.50 & 2.10 & 2.20 & 2.20 & 2.30 \\
\hline $\mathrm{PSO}_{2}^{ \pm}(\mathrm{kg} /$ people $)$ & 0.03 & 0.06 & 0.01 & 0.03 & 0.001 & 0.006 & 0.001 & 0.003 \\
\hline $\mathrm{PWD}^{ \pm}$(ton/people) & 41.45 & 42.50 & 40.42 & 41.45 & 28.16 & 29.93 & 26.95 & 28.16 \\
\hline $\mathrm{PGD}^{ \pm}$(ton/people) & 0.53 & 0.56 & 0.56 & 0.59 & 0.46 & 0.50 & 0.50 & 0.53 \\
\hline
\end{tabular}

Table A2. Important parameters of IFMOP model in scenario 1.

\begin{tabular}{|c|c|c|c|c|c|c|c|c|c|c|c|c|c|c|}
\hline \multirow[t]{2}{*}{2015} & \multicolumn{2}{|c|}{$\begin{array}{c}\text { INWWT }_{\mathbf{j}}^{ \pm} \\
(I 01-I 11), \\
\text { AGWWT }^{ \pm} \\
(I 12) \text { and } \\
\text { SEWWT }^{ \pm}(I 13) \\
(\%)\end{array}$} & \multicolumn{2}{|c|}{$\begin{array}{c}\text { INWWD }_{\mathbf{j}}^{ \pm} \\
(\mathbf{I 0 1}-\mathbf{I 1 1}), \\
\text { AGWWD }^{ \pm}(\mathbf{I 1 2}) \\
\text { and } \mathrm{SEWWD}^{ \pm}(\mathbf{I 1 3}) \\
\text { (ton/10 thousand } \\
\text { RMB Yuan) }^{2}\end{array}$} & \multicolumn{2}{|c|}{$\begin{array}{c}\text { INCOD }_{\mathrm{j}}^{ \pm}(\mathrm{IO} 1-\mathrm{I11}) \\
\mathrm{AGCOD}^{ \pm}(\mathrm{I12}) \text { and } \\
\text { SECOD }^{ \pm} \\
\text {(I13)(kg/million } \\
\text { RMB Yuan) }\end{array}$} & \multicolumn{2}{|c|}{$\begin{array}{c}\text { INNH }_{3}-\mathrm{N}_{\mathrm{j}}^{ \pm} \\
(\mathrm{I01}-\mathrm{I11}), \\
\mathrm{AGNH}_{3}-\mathrm{N}^{ \pm}(\mathrm{I12}) \\
\text { and } \mathrm{SENH}_{3}-\mathrm{N}^{ \pm} \\
(\mathrm{I13})(\mathrm{kg} / \text { million } \\
\text { RMB Yuan) }\end{array}$} & \multicolumn{2}{|c|}{$\begin{array}{c}\mathrm{INSO}_{2 \mathrm{j}}{ }^{ \pm}(\mathrm{I01}-\mathrm{I11}) \\
\mathrm{AGSO}_{2}{ }^{ \pm}(\mathrm{I12}) \text { and } \\
\mathrm{SESO}_{2}{ }^{ \pm}(\mathrm{I13}) \\
(\mathrm{kg} / \mathrm{million} \mathrm{RMB} \\
\text { Yuan) }\end{array}$} & \multicolumn{2}{|c|}{$\begin{array}{c}\text { INWD }_{\mathrm{j}}^{ \pm}(\mathrm{I} 01-\mathrm{I} 11) \\
\mathrm{AGWD}^{ \pm}(\mathrm{I12}) \text { and } \\
\mathrm{SEWD}^{ \pm}(\mathrm{I13}) \\
\text { (ton/10 thousand } \\
\text { RMB Yuan) }\end{array}$} & \multicolumn{2}{|c|}{$\begin{array}{lr}\text { INGD }_{\mathrm{j}}^{ \pm} & (\text {I01-I11), } \\
\text { AGGD }^{ \pm} & (\text {I12) } \text { and } \\
\text { SEGD }^{ \pm} & \text {(I13) } \\
(\text { ton } / 10 & \text { thousand } \\
\text { RMB Yuan) }\end{array}$} \\
\hline & $\begin{array}{l}\text { Lower } \\
\text { limits }\end{array}$ & $\begin{array}{l}\text { Upper } \\
\text { limits }\end{array}$ & $\begin{array}{l}\text { Lower } \\
\text { limits }\end{array}$ & $\begin{array}{l}\text { Upper } \\
\text { limits }\end{array}$ & $\begin{array}{l}\text { Lower } \\
\text { limits }\end{array}$ & $\begin{array}{l}\text { Upper } \\
\text { limits }\end{array}$ & $\begin{array}{l}\text { Lower } \\
\text { limits }\end{array}$ & $\begin{array}{l}\text { Upper } \\
\text { limits }\end{array}$ & $\begin{array}{l}\text { Lower } \\
\text { limits }\end{array}$ & $\begin{array}{l}\text { Upper } \\
\text { limits }\end{array}$ & $\begin{array}{l}\text { Lower } \\
\text { limits }\end{array}$ & $\begin{array}{l}\text { Upper } \\
\text { limits }\end{array}$ & $\begin{array}{l}\text { Lower } \\
\text { limits }\end{array}$ & $\begin{array}{l}\text { Upper } \\
\text { limits }\end{array}$ \\
\hline I01 & 0.60 & 0.69 & 1.68 & 2.73 & 49.76 & 81.80 & 8.29 & 13.63 & 23.51 & 48.41 & 7.12 & 10.06 & 0.55 & 0.58 \\
\hline I02 & 0.64 & 0.78 & 15.50 & 18.53 & 468.64 & 580.40 & 52.88 & 63.29 & 58.18 & 146.29 & 27.76 & 33.50 & 0.86 & 0.90 \\
\hline I03 & 0.60 & 0.69 & 11.73 & 13.63 & 629.95 & 1024.63 & 51.12 & 66.76 & 46.25 & 80.90 & 23.75 & 29.27 & 1.02 & 1.03 \\
\hline I04 & 0.60 & 0.69 & 8.24 & 10.62 & 173.82 & 230.78 & 28.97 & 38.46 & 52.8979 & 128.41 & 15.11 & 19.81 & 0.72 & 0.75 \\
\hline
\end{tabular}


Table A2. Cont.

\begin{tabular}{|c|c|c|c|c|c|c|c|c|c|c|c|c|c|c|}
\hline \multirow[t]{2}{*}{2015} & \multicolumn{2}{|c|}{$\begin{array}{c}\text { INWWT }_{\mathbf{j}}^{ \pm} \\
(I 01-I 11), \\
\text { AGWWT }^{ \pm} \\
\text {(I12) and } \\
\text { SEWWT }^{ \pm}(I 13) \\
(\%)\end{array}$} & \multicolumn{2}{|c|}{$\begin{array}{c}\text { INWWD }_{j}^{ \pm} \\
\left(\text {IO1-I11), }^{ \pm}\right. \\
\text {AGWWD }^{ \pm}(I 12) \\
\text { and SEWWD } \\
\text { (I13) (ton/10 } \\
\text { thousand RMB } \\
\text { Yuan) }\end{array}$} & \multicolumn{2}{|c|}{ 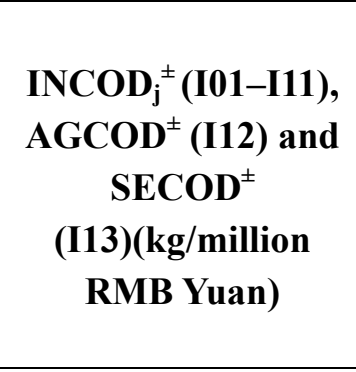 } & \multicolumn{2}{|c|}{$\begin{array}{c}\text { INNH }_{3}-\mathrm{N}_{\mathrm{j}}^{ \pm} \\
(\mathrm{I01}-\mathrm{I11}), \\
\mathrm{AGNH}_{3}-\mathrm{N}^{ \pm}(\mathrm{I12}) \\
\text { and } \mathrm{SENH}_{3}-\mathrm{N}^{ \pm} \\
\text {(I13) }(\mathrm{kg} / \text { million } \\
\text { RMB Yuan) }\end{array}$} & \multicolumn{2}{|c|}{$\begin{array}{c}\mathrm{INSO}_{2 \mathrm{j}}{ }^{ \pm}(\mathrm{I01}-\mathrm{I11}) \\
\mathrm{AGSO}_{2}{ }^{ \pm}(\mathrm{I12}) \text { and } \\
\mathrm{SESO}_{2}{ }^{ \pm}(\mathrm{I13}) \\
(\mathrm{kg} / \mathrm{million} \mathrm{RMB} \\
\text { Yuan) }\end{array}$} & \multicolumn{2}{|c|}{$\begin{array}{c}\mathbf{I N W D}_{\mathrm{j}}^{ \pm}(\mathrm{I01}-\mathrm{I11}), \\
\mathrm{AGWD}^{ \pm}(\mathrm{I12}) \text { and } \\
\text { SEWD }^{ \pm}(\mathrm{I13}) \text { (ton/10 } \\
\text { thousand RMB } \\
\text { Yuan) }\end{array}$} & \multicolumn{2}{|c|}{$\begin{array}{l}\text { INGD }_{j}^{ \pm}(\text {I01-I11), } \\
\text { AGGD }^{ \pm}(\text {I12) and } \\
\text { SEGD }^{ \pm} \text {(I13) } \\
(\text { ton/10 thousand } \\
\text { RMB Yuan) }\end{array}$} \\
\hline & $\begin{array}{l}\text { Lower } \\
\text { limits }\end{array}$ & $\begin{array}{l}\text { Upper } \\
\text { limits }\end{array}$ & $\begin{array}{l}\text { Lower } \\
\text { limits }\end{array}$ & $\begin{array}{l}\text { Upper } \\
\text { limits }\end{array}$ & $\begin{array}{l}\text { Lower } \\
\text { limits }\end{array}$ & $\begin{array}{l}\text { Upper } \\
\text { limits }\end{array}$ & $\begin{array}{l}\text { Lower } \\
\text { limits }\end{array}$ & $\begin{array}{l}\text { Upper } \\
\text { limits }\end{array}$ & $\begin{array}{l}\text { Lower } \\
\text { limits }\end{array}$ & $\begin{array}{l}\text { Upper } \\
\text { limits }\end{array}$ & $\begin{array}{l}\text { Lower } \\
\text { limits }\end{array}$ & $\begin{array}{l}\text { Upper } \\
\text { limits }\end{array}$ & $\begin{array}{l}\text { Lower } \\
\text { limits }\end{array}$ & $\begin{array}{l}\text { Upper } \\
\text { limits }\end{array}$ \\
\hline I05 & 0.60 & 0.69 & 7.91 & 9.32 & 179.75 & 229.27 & 24.22 & 30.64 & 30.53 & 60.99 & 12.20 & 15.41 & 0.36 & 0.38 \\
\hline I06 & 0.60 & 0.70 & 1.61 & 3.06 & 24.20 & 45.98 & 42.25 & 58.00 & 54.91 & 85.77 & 3.06 & 4.94 & 0.77 & 0.86 \\
\hline I07 & 0.60 & 0.69 & 12.95 & 15.41 & 558.70 & 707.18 & 99.39 & 124.62 & 415.74 & 676.32 & 30.61 & 40.01 & 0.80 & 0.84 \\
\hline I08 & 0.60 & 0.69 & 3.30 & 4.50 & 50.21 & 63.77 & 20.92 & 26.58 & 1136.47 & 1585.98 & 13.81 & 19.07 & 2.37 & 2.76 \\
\hline I09 & 0.60 & 0.69 & 71.29 & 81.33 & 4555.86 & 5185.48 & 253.19 & 288.21 & 204.36 & 426.77 & 136.35 & 158.21 & 1.45 & 1.69 \\
\hline $\mathrm{I} 10$ & 0.50 & 0.60 & 35.66 & 40.75 & 265.00 & 280.00 & 25.01 & 34.27 & 68.00 & 266.00 & 41.95 & 48.40 & 0.81 & 0.92 \\
\hline I11 & 0 & 0 & 4.12 & 4.86 & 0.00 & 0.00 & 0.00 & 0.00 & 3.92 & 11.85 & 13.51 & 16.15 & 0.23 & 0.26 \\
\hline $\mathrm{I} 12$ & 0 & 0 & 482.18 & 596.64 & 960.00 & 1020.00 & 103.00 & 107.00 & 110.33 & 177.11 & 1178.00 & 1356.00 & 1.69 & 1.73 \\
\hline $\mathrm{I} 13$ & 0.90 & 0.95 & 9.28 & 10.37 & 470.33 & 482.25 & 56.12 & 57.88 & 6.83 & 26.04 & 12.33 & 15.94 & 0.28 & 0.32 \\
\hline \multirow[t]{2}{*}{2020} & \multicolumn{2}{|c|}{$\begin{array}{c}\text { INWWT }_{\mathbf{j}}^{ \pm} \\
(\mathbf{I 0 1}-\mathbf{I 1 1}), \\
\mathbf{A G W W T}^{ \pm} \\
\text {(I12) and } \\
\text { SEWWT }^{ \pm}(\mathbf{I 1 3}) \\
(\%)\end{array}$} & \multicolumn{2}{|c|}{$\begin{array}{c}\text { INWWD }_{j}^{ \pm} \\
(I 01-I 11), \\
\text { AGWWD }^{ \pm}(I 12) \\
\text { and SEWWD } \\
\text { (I13) (ton/10 } \\
\text { thousand RMB } \\
\text { Yuan) }\end{array}$} & \multicolumn{2}{|c|}{$\begin{array}{c}\operatorname{INCOD}_{\mathrm{j}}^{ \pm}(\mathrm{I01}-\mathrm{I11}) \\
\operatorname{AGCOD}^{ \pm}(\mathrm{I12}) \text { and } \\
\operatorname{SECOD}^{ \pm}(\mathrm{I13}) \\
\left(\mathrm{kg} / \mathrm{million}_{\mathrm{RMB}}\right. \\
\text { Yuan) }\end{array}$} & \multicolumn{2}{|c|}{$\begin{array}{c}\mathrm{INNH}_{3}-\mathrm{N}_{\mathrm{j}}^{ \pm} \\
(\mathrm{I01}-\mathrm{I11}), \\
\mathrm{AGNH}_{3}-\mathrm{N}^{ \pm}(\mathrm{I12}) \\
\text { and } \mathrm{SENH}_{3}-\mathrm{N}^{ \pm} \\
\text {(I13) }(\mathbf{k g} / \text { million } \\
\text { RMB Yuan) }\end{array}$} & \multicolumn{2}{|c|}{$\begin{array}{c}\text { INSO }_{2 \mathrm{j}}^{ \pm}(\mathrm{I01}-\mathrm{I11}) \\
\mathrm{AGSO}_{2}^{ \pm} \text {(I12) and } \\
\mathrm{SESO}_{2}{ }^{ \pm}(\mathrm{I13}) \\
(\mathrm{kg} / \mathrm{million} \mathrm{RMB} \\
\text { Yuan) }\end{array}$} & \multicolumn{2}{|c|}{$\begin{array}{c}\mathrm{INWD}_{\mathrm{j}}^{ \pm}(\mathrm{I01}-\mathrm{I11}) \\
\mathrm{AGWD}^{ \pm}(\mathrm{I12}) \text { and } \\
\mathrm{SEWD}^{ \pm}(\mathrm{I13}) \text { (ton/10 } \\
\text { thousand RMB } \\
\text { Yuan) }\end{array}$} & \multicolumn{2}{|c|}{$\begin{array}{l}\text { INGD }_{j}^{ \pm}\left({ }^{ \pm 01}-I 11\right) \\
\text { AGGD }^{ \pm}(\text {I12) and } \\
\text { SEGD }^{ \pm} \text {(I13) } \\
(\text { ton/10 thousand } \\
\text { RMB Yuan) }\end{array}$} \\
\hline & $\begin{array}{l}\text { Lower } \\
\text { limits }\end{array}$ & $\begin{array}{l}\text { Upper } \\
\text { limits }\end{array}$ & $\begin{array}{l}\text { Lower } \\
\text { limits }\end{array}$ & $\begin{array}{l}\text { Upper } \\
\text { limits }\end{array}$ & $\begin{array}{l}\text { Lower } \\
\text { limits }\end{array}$ & $\begin{array}{l}\text { Upper } \\
\text { limits }\end{array}$ & $\begin{array}{l}\text { Lower } \\
\text { limits }\end{array}$ & $\begin{array}{l}\text { Upper } \\
\text { limits }\end{array}$ & $\begin{array}{l}\text { Lower } \\
\text { limits }\end{array}$ & $\begin{array}{l}\text { Upper } \\
\text { limits }\end{array}$ & $\begin{array}{l}\text { Lower } \\
\text { limits }\end{array}$ & $\begin{array}{l}\text { Upper } \\
\text { limits }\end{array}$ & $\begin{array}{l}\text { Lower } \\
\text { limits }\end{array}$ & $\begin{array}{l}\text { Upper } \\
\text { limits }\end{array}$ \\
\hline I01 & 0.69 & 0.8 & 0.63 & 1.68 & 18.96 & 49.76 & 3.16 & 8.29 & 11.41 & 23.51 & 4.40 & 7.12 & 0.54 & 0.55 \\
\hline $\mathrm{I} 02$ & 0.78 & 0.95 & 12.47 & 15.5 & 357.27 & 468.64 & 42.46 & 52.88 & 14.53 & 58.19 & 22.39 & 27.76 & 0.84 & 0.86 \\
\hline
\end{tabular}


Table A2. Cont.

\begin{tabular}{|c|c|c|c|c|c|c|c|c|c|c|c|c|c|c|}
\hline \multirow[t]{2}{*}{2020} & \multicolumn{2}{|c|}{$\begin{array}{c}\text { INWWT }_{\mathbf{j}}^{ \pm} \\
(\mathbf{I 0 1}-\mathbf{I 1 1}), \\
\text { AGWWT }^{ \pm} \\
\text {(I12) and } \\
\text { SEWWT }^{ \pm}(\mathbf{I 1 3}) \\
(\%)\end{array}$} & \multicolumn{2}{|c|}{ 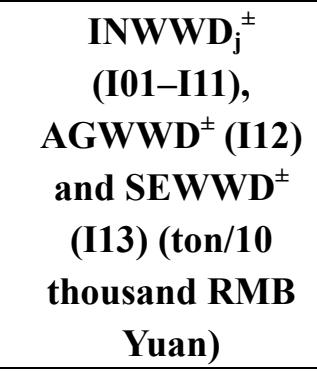 } & \multicolumn{2}{|c|}{$\begin{array}{c}\mathrm{INCOD}_{\mathrm{j}}^{ \pm}(\mathrm{I} 01-\mathrm{I} 11) \\
\mathrm{AGCOD}^{ \pm}(\mathrm{I} 12) \text { and } \\
\mathrm{SECOD}^{ \pm}(\mathrm{I13}) \\
(\mathrm{kg} / \mathrm{million} \mathrm{RMB} \\
\text { Yuan) }\end{array}$} & \multicolumn{2}{|c|}{$\begin{array}{c}\mathrm{INNH}_{3}-\mathrm{N}_{\mathrm{j}}^{ \pm} \\
(\mathrm{I01}-\mathrm{I11}), \\
\mathrm{AGNH}_{3}-\mathrm{N}^{ \pm}(\mathrm{I12}) \\
\text { and } \mathrm{SENH}_{3}-\mathrm{N}^{ \pm} \\
\text {(I13) (kg/million } \\
\text { RMB Yuan) }\end{array}$} & \multicolumn{2}{|c|}{$\begin{array}{c}\mathrm{INSO}_{2 \mathrm{j}}{ }^{ \pm}(\mathrm{I} 01-\mathrm{I} 11) \\
\mathrm{AGSO}_{2}{ }^{ \pm}(\mathrm{I1}) \text { and } \\
\mathrm{SESO}_{2}{ }^{ \pm}(\mathrm{I13}) \\
(\mathrm{kg} / \text { million RMB } \\
\text { Yuan) }\end{array}$} & \multicolumn{2}{|c|}{$\begin{array}{c}\text { INWD }_{\mathrm{j}}^{ \pm}(\mathrm{I01}-\mathrm{I11}) \\
\mathrm{AGWD}^{ \pm}(\mathrm{I12}) \text { and } \\
\mathrm{SEWD}^{ \pm}(\mathrm{I13})(\text { ton } / 10 \\
\text { thousand RMB } \\
\text { Yuan) }\end{array}$} & \multicolumn{2}{|c|}{$\begin{array}{l}\text { INGD }_{\mathbf{j}}^{ \pm}(\text {I01-I11) } \\
\text { AGGD }^{ \pm}(\text {I12) and } \\
\text { SEGD }^{ \pm} \\
\text {(ton/10 thousand } \\
\text { RMB Yuan) }\end{array}$} \\
\hline & $\begin{array}{l}\text { Lower } \\
\text { limits }\end{array}$ & $\begin{array}{l}\text { Upper } \\
\text { limits }\end{array}$ & $\begin{array}{l}\text { Lower } \\
\text { limits }\end{array}$ & $\begin{array}{l}\text { Upper } \\
\text { limits }\end{array}$ & $\begin{array}{l}\text { Lower } \\
\text { limits }\end{array}$ & $\begin{array}{l}\text { Upper } \\
\text { limits }\end{array}$ & $\begin{array}{l}\text { Lower } \\
\text { limits }\end{array}$ & $\begin{array}{l}\text { Upper } \\
\text { limits }\end{array}$ & $\begin{array}{l}\text { Lower } \\
\text { limits }\end{array}$ & $\begin{array}{l}\text { Upper } \\
\text { limits }\end{array}$ & $\begin{array}{l}\text { Lower } \\
\text { limits }\end{array}$ & $\begin{array}{l}\text { Upper } \\
\text { limits }\end{array}$ & $\begin{array}{l}\text { Lower } \\
\text { limits }\end{array}$ & $\begin{array}{l}\text { Upper } \\
\text { limits }\end{array}$ \\
\hline I03 & 0.69 & 0.8 & 9.83 & 11.73 & 224.72 & 629.95 & 36.90 & 51.12 & 25.33 & 46.25 & 19.73 & 23.75 & 1.00 & 1.02 \\
\hline I04 & 0.69 & 0.8 & 5.86 & 8.24 & 123.71 & 173.82 & 20.62 & 28.97 & 15.04 & 52.90 & 11.13 & 15.11 & 0.70 & 0.72 \\
\hline I05 & 0.69 & 0.8 & 6.5 & 7.91 & 130.91 & 179.75 & 17.89 & 24.22 & 10.12 & 30.53 & 9.20 & 12.20 & 0.35 & 0.36 \\
\hline I06 & 0.7 & 0.8 & 0.16 & 1.61 & 2.43 & 24.20 & 26.50 & 42.25 & 24.05 & 54.91 & 1.17 & 3.06 & 0.69 & 0.78 \\
\hline I07 & 0.69 & 0.8 & 10.49 & 12.95 & 446.10 & 558.70 & 80.11 & 99.39 & 201.59 & 415.75 & 23.75 & 30.61 & 0.78 & 0.80 \\
\hline I08 & 0.69 & 0.8 & 2.11 & 3.3 & 29.84 & 50.21 & 12.43 & 20.92 & 691.06 & 1136.47 & 9.22 & 13.81 & 2.15 & 2.37 \\
\hline I09 & 0.69 & 0.8 & 61.24 & 71.29 & 3970.14 & 4555.86 & 220.63 & 253.19 & 66.50 & 204.36 & 116.90 & 136.35 & 1.31 & 1.45 \\
\hline $\mathrm{I} 10$ & 0.65 & 0.66 & 30.57 & 35.66 & 250.00 & 265.00 & 15.75 & 25.01 & 167.00 & 68.00 & 35.51 & 41.95 & 0.70 & 0.81 \\
\hline I11 & 0 & 0 & 3.39 & 4.12 & 0.00 & 0.00 & 0.00 & 0.00 & 1.07 & 3.92 & 11.31 & 13.51 & 0.21 & 0.23 \\
\hline $\mathrm{I} 12$ & 0 & 0 & 420.00 & 482.18 & 930.00 & 960.00 & 99.00 & 103.00 & 11.41 & 23.51 & 1000.00 & 1178.00 & 1.66 & 1.69 \\
\hline $\mathrm{I} 13$ & 0.95 & 1 & 8.19 & 9.28 & 461.04 & 470.33 & 54.49 & 56.12 & 1.48 & 6.83 & 11.15 & 12.33 & 0.25 & 0.28 \\
\hline
\end{tabular}


Table A3. Important parameters of IFMOP model in scenario 2.

\begin{tabular}{|c|c|c|c|c|c|c|c|c|c|c|c|c|c|c|}
\hline \multirow[t]{2}{*}{2015} & \multicolumn{2}{|c|}{$\begin{array}{c}\text { INWWT }_{\mathbf{j}}^{ \pm} \\
(\mathbf{I 0 1}-\mathbf{I 1 1}), \\
\text { AGWWT }^{ \pm} \\
\text {(I12) and } \\
\text { SEWWT }^{ \pm}(\mathbf{I 1 3}) \\
(\%)\end{array}$} & \multicolumn{2}{|c|}{$\begin{array}{c}\text { INWWD }_{j}^{ \pm} \\
(I 01-I 11), \\
\text { AGWWD }^{ \pm}(I 12) \\
\text { and SEWWD } \\
\text { (I13) (ton/10 } \\
\text { thousand RMB } \\
\text { Yuan) }\end{array}$} & \multicolumn{2}{|c|}{$\begin{array}{c}\operatorname{INCOD}_{\mathrm{j}}^{ \pm}(\mathrm{I01}-\mathrm{I11}) \\
\mathrm{AGCOD}^{ \pm}(\mathrm{I12}) \text { and } \\
\operatorname{SECOD}^{ \pm}(\mathrm{I13}) \\
\left(\mathrm{kg} / \mathrm{million}_{\mathrm{RMB}}\right. \\
\text { Yuan) }\end{array}$} & \multicolumn{2}{|c|}{$\begin{array}{c}\text { INNH }_{3}-\mathbf{N}_{\mathrm{j}}^{ \pm} \\
(\mathbf{I 0 1}-\mathrm{I11}), \\
\mathrm{AGNH}_{3}-\mathrm{N}^{ \pm}(\mathrm{I12}) \\
\text { and } \mathrm{SENH}_{3}-\mathrm{N}^{ \pm} \\
\text {(I13) }(\mathrm{kg} / \mathrm{million} \\
\text { RMB Yuan) }\end{array}$} & \multicolumn{2}{|c|}{$\begin{array}{c}\mathrm{INSO}_{2 \mathrm{j}}{ }^{ \pm}(\mathrm{I01}-\mathrm{I11}), \\
\mathrm{AGSO}_{2}{ }^{ \pm}(\mathrm{I12}) \text { and } \\
\mathrm{SESO}_{2}{ }^{ \pm}(\mathrm{I13}) \\
(\mathrm{kg} / \mathrm{million} \mathrm{RMB} \\
\text { Yuan) }\end{array}$} & \multicolumn{2}{|c|}{$\begin{array}{c}\text { INWD }_{\mathrm{j}}^{ \pm}(\mathrm{I01}-\mathrm{I11}), \\
\mathrm{AGWD}^{ \pm}(\mathrm{I12}) \text { and } \\
\mathrm{SEWD}^{ \pm}(\mathrm{I13})(\text { ton } / 10 \\
\text { thousand RMB } \\
\text { Yuan) }\end{array}$} & \multicolumn{2}{|c|}{$\begin{array}{c}\text { INGD }_{\mathrm{j}}^{ \pm}(\mathrm{I01}-\mathrm{I11}), \\
\mathrm{AGGD}^{ \pm}(\mathrm{I12}) \text { and } \\
\mathrm{SEGD}^{ \pm}(\mathrm{I13}) \\
\text { (ton/10 thousand } \\
\text { RMB Yuan) }^{2}\end{array}$} \\
\hline & $\begin{array}{l}\text { Lower } \\
\text { limits }\end{array}$ & $\begin{array}{l}\text { Upper } \\
\text { limits }\end{array}$ & $\begin{array}{l}\text { Lower } \\
\text { limits }\end{array}$ & $\begin{array}{l}\text { Upper } \\
\text { limits }\end{array}$ & $\begin{array}{l}\text { Lower } \\
\text { limits }\end{array}$ & $\begin{array}{l}\text { Upper } \\
\text { limits }\end{array}$ & $\begin{array}{l}\text { Lower } \\
\text { limits }\end{array}$ & $\begin{array}{l}\text { Upper } \\
\text { limits }\end{array}$ & $\begin{array}{l}\text { Lower } \\
\text { limits }\end{array}$ & $\begin{array}{l}\text { Upper } \\
\text { limits }\end{array}$ & $\begin{array}{l}\text { Lower } \\
\text { limits }\end{array}$ & $\begin{array}{l}\text { Upper } \\
\text { limits }\end{array}$ & $\begin{array}{l}\text { Lower } \\
\text { limits }\end{array}$ & $\begin{array}{l}\text { Upper } \\
\text { limits }\end{array}$ \\
\hline I01 & 0.60 & 0.69 & 2.71 & 4.82 & 41.00 & 72.00 & 6.80 & 12.00 & 20.00 & 40.00 & 5.83 & 8.92 & 0.41 & 0.48 \\
\hline I02 & 0.64 & 0.78 & 6.63 & 15.49 & 100.00 & 350.00 & 17.00 & 42.00 & 44.00 & 120.00 & 12.49 & 23.80 & 0.64 & 0.75 \\
\hline I03 & 0.60 & 0.69 & 9.26 & 16.37 & 140.00 & 250.00 & 20.00 & 40.00 & 33.00 & 67.00 & 15.60 & 24.70 & 0.73 & 0.85 \\
\hline I04 & 0.60 & 0.69 & 6.70 & 12.09 & 100.00 & 180.00 & 17.00 & 30.00 & 40.00 & 110.00 & 10.22 & 16.53 & 0.54 & 0.62 \\
\hline I05 & 0.60 & 0.69 & 4.82 & 9.36 & 70.00 & 170.00 & 12.00 & 25.00 & 23.00 & 51.00 & 5.84 & 11.61 & 0.27 & 0.32 \\
\hline I06 & 0.50 & 0.70 & 1.54 & 3.06 & 13.00 & 83.00 & 42.00 & 58.00 & 0.00 & 0.00 & 3.06 & 4.94 & 0.76 & 0.89 \\
\hline I07 & 0.60 & 0.69 & 6.30 & 11.80 & 190.00 & 350.00 & 31.00 & 59.00 & 390.00 & 640.00 & 20.79 & 30.74 & 0.6 & 0.69 \\
\hline I08 & 0.60 & 0.69 & 2.15 & 3.91 & 26.00 & 47.00 & 11.00 & 20.00 & 1000.00 & 1500.00 & 10.02 & 16.07 & 2.37 & 2.76 \\
\hline I09 & 0.60 & 0.69 & 18.64 & 63.27 & 840.00 & 2800.00 & 47.00 & 160.00 & 200.00 & 430.00 & 41.48 & 96.82 & 1.45 & 1.69 \\
\hline $\mathrm{I} 10$ & 0.50 & 0.65 & 21.23 & 30.89 & 120.00 & 190.00 & 26.00 & 34.00 & 170.00 & 270.00 & 26.90 & 37.98 & 0.67 & 0.78 \\
\hline I11 & 0.50 & 0.65 & 0.00 & 0.00 & 0.00 & 0.00 & 0.00 & 0.00 & 5.20 & 14.00 & 13.10 & 15.65 & 0.3 & 0.32 \\
\hline $\mathrm{I} 12$ & 0.00 & 0.00 & 450.37 & 526.24 & 1020.00 & 1070.00 & 103.00 & 107.00 & 80.00 & 160.00 & 1164.00 & 1355.00 & 1.51 & 1.59 \\
\hline I13 & 0.60 & 0.80 & 7.53 & 12.76 & 470.00 & 480.00 & 56.00 & 58.00 & 8.70 & 30.00 & 9.41 & 15.94 & 0.35 & 0.37 \\
\hline
\end{tabular}


Table A3. Cont.

\begin{tabular}{|c|c|c|c|c|c|c|c|c|c|c|c|c|c|c|}
\hline \multirow[t]{2}{*}{2020} & \multicolumn{2}{|c|}{$\begin{array}{c}\text { INWWT }_{\mathbf{j}}^{ \pm} \\
(\text {I01-I11), } \\
\text { AGWWT }^{ \pm} \\
\text {(I12) and } \\
\text { SEWWT }^{ \pm}(\mathbf{I 1 3}) \\
(\%)\end{array}$} & \multicolumn{2}{|c|}{$\begin{array}{c}\text { INWWD }_{j}^{ \pm} \\
\left(\text {I01-I11), }^{ \pm}\right. \\
\text {AGWWD }^{ \pm}(\mathbf{I 1 2}) \\
\text { and SEWWD } \\
\text { (I13) (ton/10 }^{ \pm} \\
\text {thousand RMB } \\
\text { Yuan) }\end{array}$} & \multicolumn{2}{|c|}{$\begin{array}{c}\mathrm{INCOD}_{\mathrm{j}}^{ \pm}(\mathrm{I01}-\mathrm{I11}) \\
\mathrm{AGCOD}^{ \pm}(\mathrm{I12}) \text { and } \\
\operatorname{SECOD}^{ \pm}(\mathrm{I13}) \\
\left(\mathrm{kg} / \mathrm{million}_{\mathrm{RMB}}\right. \\
\text { Yuan) }\end{array}$} & \multicolumn{2}{|c|}{$\begin{array}{c}\mathrm{INNH}_{3}-\mathrm{N}_{\mathrm{j}}^{ \pm} \\
(\mathbf{I 0 1}-\mathrm{I11}), \\
\mathrm{AGNH}_{3}-\mathrm{N}^{ \pm}(\mathrm{I12}) \\
\text { and } \mathrm{SENH}_{3}-\mathrm{N}^{ \pm} \\
(\mathrm{I13})(\mathrm{kg} / \mathrm{million} \\
\text { RMB Yuan) }\end{array}$} & \multicolumn{2}{|c|}{$\begin{array}{c}\mathrm{INSO}_{2 \mathrm{j}}{ }^{ \pm}(\mathrm{I01}-\mathrm{I11}) \\
\mathrm{AGSO}_{2}{ }^{ \pm}(\mathrm{I12}) \text { and } \\
\mathrm{SESO}_{2}{ }^{ \pm}(\mathrm{I13}) \\
\text { (kg/million RMB } \\
\text { Yuan) }\end{array}$} & \multicolumn{2}{|c|}{$\begin{array}{c}\mathbf{I N W D}_{\mathrm{j}}^{ \pm}(\mathrm{I01}-\mathrm{I11}) \\
\mathrm{AGWD}^{ \pm}(\mathrm{I12}) \text { and } \\
\mathrm{SEWD}^{ \pm}(\mathrm{I13}) \text { (ton/10 } \\
\text { thousand RMB } \\
\text { Yuan) }\end{array}$} & \multicolumn{2}{|c|}{$\begin{array}{c}\text { INGD }_{\mathbf{j}}^{ \pm}(\mathrm{I01}-\mathrm{I11}) \\
\mathrm{AGGD}^{ \pm}(\mathrm{I12}) \text { and } \\
\mathrm{SEGD}^{ \pm}(\mathrm{I13}) \\
\text { (ton/10 thousand } \\
\text { RMB Yuan) }\end{array}$} \\
\hline & $\begin{array}{l}\text { Lower } \\
\text { limits }\end{array}$ & $\begin{array}{l}\text { Upper } \\
\text { limits }\end{array}$ & $\begin{array}{l}\text { Lower } \\
\text { limits }\end{array}$ & $\begin{array}{l}\text { Upper } \\
\text { limits }\end{array}$ & $\begin{array}{l}\text { Lower } \\
\text { limits }\end{array}$ & $\begin{array}{l}\text { Upper } \\
\text { limits }\end{array}$ & $\begin{array}{l}\text { Lower } \\
\text { limits } \\
\end{array}$ & $\begin{array}{l}\text { Upper } \\
\text { limits }\end{array}$ & $\begin{array}{l}\text { Lower } \\
\text { limits } \\
\end{array}$ & $\begin{array}{l}\text { Upper } \\
\text { limits }\end{array}$ & $\begin{array}{l}\text { Lower } \\
\text { limits } \\
\end{array}$ & $\begin{array}{l}\text { Upper } \\
\text { limits }\end{array}$ & $\begin{array}{l}\text { Lower } \\
\text { limits }\end{array}$ & $\begin{array}{l}\text { Upper } \\
\text { limits }\end{array}$ \\
\hline I01 & 0.69 & 0.80 & 0.98 & 2.71 & 15.00 & 41.00 & 2.50 & 6.80 & 7.30 & 20.00 & 3.42 & 5.83 & 0.34 & 0.41 \\
\hline I02 & 0.78 & 0.95 & 0.61 & 6.63 & 9.00 & 100.00 & 1.50 & 17.00 & 9.00 & 44.00 & 5.20 & 12.49 & 0.53 & 0.64 \\
\hline $\mathrm{I} 03$ & 0.69 & 0.80 & 2.89 & 9.26 & 40.00 & 140.00 & 7.00 & 20.00 & 15.00 & 170.00 & 7.90 & 15.60 & 0.61 & 0.73 \\
\hline I04 & 0.69 & 0.80 & 2.08 & 6.70 & 31.00 & 100.00 & 5.20 & 17.00 & 9.60 & 40.00 & 4.97 & 10.22 & 0.45 & 0.54 \\
\hline I05 & 0.69 & 0.80 & 0.33 & 4.82 & 4.90 & 70.00 & 0.80 & 12.00 & 6.50 & 23.00 & 0.91 & 5.84 & 0.22 & 0.27 \\
\hline I06 & 0.70 & 0.90 & 0.16 & 1.54 & 4.50 & 13.00 & 26.00 & 42.00 & 0.00 & 0.00 & 1.17 & 3.06 & 0.63 & 0.76 \\
\hline I07 & 0.69 & 0.80 & 1.30 & 6.30 & 39.00 & 190.00 & 6.50 & 31.00 & 180.00 & 390.00 & 12.65 & 20.79 & 0.5 & 0.60 \\
\hline I08 & 0.69 & 0.80 & 0.25 & 2.15 & 3.00 & 26.00 & 1.27 & 11.00 & 580.00 & 1000.00 & 5.48 & 10.02 & 1.98 & 2.37 \\
\hline I09 & 0.69 & 0.80 & 3.32 & 18.64 & 150.00 & 840.00 & 8.30 & 47.00 & 61.00 & 200.00 & 19.34 & 41.48 & 1.21 & 1.45 \\
\hline $\mathrm{I} 10$ & 0.65 & 0.80 & 11.73 & 21.23 & 50.00 & 120.00 & 15.00 & 26.00 & 70.00 & 170.00 & 15.91 & 26.90 & 0.56 & 0.67 \\
\hline I11 & 0.65 & 0.80 & 0.00 & 0.00 & 0.00 & 0.00 & 0.00 & 0.00 & 1.50 & 5.20 & 11.25 & 13.10 & 0.29 & 0.30 \\
\hline $\mathrm{I} 12$ & 0.00 & 0.00 & 390.18 & 450.37 & 900.00 & 1020.00 & 99.00 & 103.00 & 40.00 & 80.00 & 1000.00 & 1164.00 & 1.48 & 1.51 \\
\hline $\mathrm{I} 13$ & 0.80 & 1.00 & 4.45 & 7.53 & 450.00 & 470.00 & 50.00 & 56.00 & 2.00 & 8.70 & 5.56 & 9.41 & 0.34 & 0.35 \\
\hline
\end{tabular}

(C) 2013 by the authors; licensee MDPI, Basel, Switzerland. This article is an open access article distributed under the terms and conditions of the Creative Commons Attribution license (http://creativecommons.org/licenses/by/3.0/). 